\title{
Serotonin Differentially Regulates L5 Pyramidal Cell Classes of the Medial Prefrontal Cortex in Rats and Mice
}

\author{
Mary C. Elliott, ${ }^{(}$Peter M. Tanaka, ${ }^{-}$Ryan W. Schwark, and ${ }^{\circledR}$ Rodrigo Andrade
}

DOI:http://dx.doi.org/10.1523/ENEURO.0305-17.2018

Department of Pharmacology, Wayne State University School of Medicine, Detroit, MI

\begin{abstract}
The prefrontal cortex receives a dense serotonergic innervation that plays an important role in its regulation. However, how serotonin regulates different pyramidal and interneuron cell classes in this area is incompletely understood. Previous work in rats has shown that serotonin differentially regulates two classes of pyramidal cells in layer 5. It excites one class by activating $5-\mathrm{HT}_{2 \mathrm{~A}}$ receptors, whereas it more subtly modulates the integrative properties of the other by co-activating $5-\mathrm{HT}_{1 \mathrm{~A}}$ and $5-\mathrm{HT}_{2 \mathrm{~A}}$ receptors. Here we have used electrophysiological recordings, combined with retrograde labeling and morphological reconstruction, to show that the first cell class corresponds to long range corticofugal neurons and the second corresponds to intratelencephalic neurons. These results suggest that, in rats, serotonin facilitates subcortical output while more subtly modulating cortico-cortical and cortico-striatal output. Interestingly, these results obtained in rats differ from those previously reported for mouse prefrontal cortex. Therefore we reinvestigated the effects of serotonin in mice and confirmed that serotonin predominantly activates inhibitory $5-\mathrm{HT}_{1 \mathrm{~A}}$ receptors on long-range corticofugal cells. Thus serotonin exerts opposite effects on these cells in rats and mice. Finally, we determined whether cortical serotonin responsiveness in mice is regulated during development. Serotonin elicited predominantly depolarizing inward current responses during the early postnatal period, whereas inhibitory $5-\mathrm{HT}_{1 \mathrm{~A}}$ receptor-mediated responses did not become evident until the end of the second postnatal week. These results reveal commonalities as well as unexpected differences in the serotonergic regulation of long-range corticofugal and intratelencephalic neurons of layer 5 in rat and mouse.
\end{abstract}

Key words: Corticofugal; development; intratelencephalic; prefrontal cortex; pyramidal cell; serotonin

\section{Significance Statement}

Serotonin is thought to be an important regulator of prefrontal cortex function. Previous work has focused on layer 5 and identified heterogeneous effects of serotonin on pyramidal cells. This is consistent with the coexistence of long-range corticofugal and intratelencephalic pyramidal cells in this layer. However, the specific effects of serotonin reported in rats and mice differ, making it difficult to understand how serotonin regulates this area. Here we elucidate the effects of serotonin on both cell classes in rats and show that they differ from those in mice. These results extend our understanding of the effects of serotonin in layer 5 and suggest caution when extrapolating across rodents as we try to understand the functional role of serotonin in prefrontal cortex.

Received August 29, 2017; accepted January 12, 2018; First published January 29, 2018.

The authors declare no competing financial interests.
Author contributions: M.C. Elliot, P.M. Tanaka, R.W. Schwark, and R. Andrade performed the experiments and the data analysis. M.C. Elliot and R. Andrade wrote the manuscript. 


\section{Introduction}

The cerebral cortex, including the prefrontal area, receives a dense serotonergic innervation originating predominantly from the dorsal raphe nucleus with a secondary contribution from the median raphe nucleus (Vertes, 1991; Van Bockstaele et al., 1993; Bang et al., 2012). Previous electrophysiological studies in vivo and in vitro have shown that the effects of serotonin on pyramidal cells and interneurons of cortex are highly variable, and this is thought to reflect the expression of varying serotonin receptor subtype combinations in different neuronal classes (Andrade and Beck, 2010; Andrade, 2011). However, exactly how serotonin regulates specific pyramidal cell and interneuron cell classes in cortex remains incompletely understood. Of particular interest is layer 5 (L5), which harbors two distinct subpopulations of pyramidal cells, one giving rise to long-range corticofugal projection and the other giving rise to intratelencephalic projections (Koester and O'Leary, 1993, reviewed by Molnar and Cheung, 2006; Molyneaux et al., 2007; Leone et al., 2008). These two populations are thought to differ not only in terms of their projections, but also in terms of their genomic regulation, electrophysiological properties, morphology, and neuromodulation (e.g. Molnar and Cheung, 2006; Hattox and Nelson, 2007; Dembrow et al., 2010; Avesar and Gulledge, 2012; Gee et al., 2012; van Aerde et al., 2015; Tasic et al., 2016).

Previous work in the rat medial prefrontal cortex (mPFC) has identified two distinct populations of pyramidal cells in L5 that show strikingly different modulation by serotonin (Beique et al., 2007). One of these cell populations expresses $5-\mathrm{HT}_{1 \mathrm{~A}}$ and $5-\mathrm{HT}_{2 \mathrm{~A}}$ receptors and responds to applications of serotonin with biphasic changes in excitability and a remodeling of its input-output relationship (Araneda and Andrade, 1991). The second, smaller, population expresses solely $5-\mathrm{HT}_{2 \mathrm{~A}}$ receptors and is strongly depolarized and excited by administration of serotonin. The relationship of these electrophysiologically and pharmacologically defined cell types to the long range corticofugal/intratelencephalic typology has not been addressed. More recent work in mouse mPFC has also reported a differential effect of serotonin on pyramidal cells of L5 (Avesar and Gulledge, 2012; Stephens et al., 2014). These studies showed that inhibitory $5-\mathrm{HT}_{1 \mathrm{~A}}$ receptors are expressed in both identified commissural (i.e., intratelencephalic) and corticopontine (i.e., long-range corticofugal) pyramidal cells of L5, whereas excitatory $5-\mathrm{HT}_{2 \mathrm{~A}}$ receptors are expressed predominantly on commissural pyramidal neurons. As a result, 5-HT selectively excites commissural/intratelencephalic L5 neurons. At the

This work was supported by $\mathrm{NIH}$ grants $\mathrm{MH} 43985$ and $\mathrm{MH} 100850$ and the State of Michigan.

Correspondence should be addressed to Rodrigo Andrade, Department of Pharmacology, Wayne State University School of Medicine, 3108 Scott Hall, 540 E Canfield, Detroit, MI 48201. E-mail: randrade@med.wayne.edu.

DOI:http://dx.doi.org/10.1523/ENEURO.0305-17.2018

Copyright (C) 2018 Elliott et al.

This is an open-access article distributed under the terms of the Creative Commons Attribution 4.0 International license, which permits unrestricted use, distribution and reproduction in any medium provided that the original work is properly attributed. present time, it is difficult to mesh these results in rats and mice into a coherent understanding of the effects of serotonin in L5 of the mPFC. Therefore, in the current work, we have readdressed the effect of serotonin on pyramidal cells in $L 5$ in rats and mice.

\section{Materials and Methods}

Coronal slices from the mPFC were prepared from male and female Sprague-Dawley rats aged postnatal day 21 (P21) to P31 and male and female Swiss-Webster mice aged P7 to adult. Rats and mice were deeply anesthetized by inhalation using isoflurane and killed by decapitation. The brain was quickly removed from the skull, cooled in ice-cold Ringer (composition in mM: $119 \mathrm{NaCl}, 2.5 \mathrm{KCl}$, $1.3 \mathrm{MgSO}_{4}, 2.5 \mathrm{CaCl}_{2}, 1 \mathrm{NaH}_{2} \mathrm{PO}_{4}, 26.2 \mathrm{NaHCO}_{3}$, and 11 glucose) supplemented with $10 \mathrm{~mm}$ Hepes, and bubbled to saturation with $95 \% \mathrm{O}_{2}-5 \% \mathrm{CO}_{2}$. In some experiments, brains were cooled and sectioned in a modified Ringer solution in which sodium was substituted with NMDG (composition in mM: 119 NMDG, brought to $\mathrm{pH} 7.3$ with $\mathrm{HCl}, 2.5 \mathrm{KCl}, 7 \mathrm{MgSO}_{4}, 0.5 \mathrm{CaCl}_{2}, 1 \mathrm{NaH}_{2} \mathrm{PO}_{4}, 26.2$ $\mathrm{NaHCO}_{3}, 22$ glucose; 10 Hepes). The anterior portion of the brain was isolated, mounted to a stage with cyanoacrylate glue, then sliced (300- $\mu \mathrm{m}$ nominal thickness) using a Vibratome series 1000. Slices were transferred to a holding chamber that had an initial temperature of $35^{\circ} \mathrm{C}$ but was allowed to equilibrate to room temperature after the addition of slices. Slices spent a minimum of $1 \mathrm{~h}$ in the holding chamber before recording.

\section{Electrophysiological recordings}

Whole-cell patch-clamp recordings were obtained from pyramidal neurons of the anterior cingulate or prelimbic regions of the mPFC. Cortical slices were transferred to a recording chamber on the stage of an upright microscope (Olympus BX50WI or Nikon E600), where they were continually perfused with Ringer at $31 \pm 1^{\circ} \mathrm{C}$ bubbled to saturation with $95 \% \quad \mathrm{O}_{2}-5 \% \quad \mathrm{CO}_{2}$. Slices were imaged using differential interference contrast (DIC), and pyramidal cells of L5 were identified using their position within the slice.

All recordings were performed using EPC 10 amplifiers (HEKA Instruments), and data were collected under the control of PatchMaster (HEKA Instruments). The recording pipettes were pulled from borosilicate glass $(1.2 \mathrm{~mm}$, Sutter Instruments) and filled with intracellular solution of the following composition (in $\mathrm{mm}$ ): $120 \mathrm{KMeSO}_{4}, 5 \mathrm{KCl}$, $5 \mathrm{NaCl}, 0.02$ EGTA, 10 Hepes, $1 \mathrm{MgCl}_{2}, 10$ phosphocreatine, 4 ATP Mg salt, 0.3 GTP Na salt, 10 inositol, pH 7.3. Electrode resistance ranged from 2.5 to $4 \mathrm{M} \Omega$. For voltage-clamp experiments, cells were held at $-60 \mathrm{mV}$. Cells referred to as type I pyramidal neurons seem to be less numerous than their type II counterparts in the mPFC. Therefore, to ensure an adequate sample size, cells of this type were not sampled at random, but instead were specifically targeted based on laminar position and soma size.

Calcium-activated afterhyperpolarization currents were triggered using a 100-ms depolarizing step to $10 \mathrm{mV}$ to allow calcium into the cell as previously described (Villalobos and Andrade, 2010). The amplitude of the medium 
afterhyperpolarization current $\left(\mathrm{I}_{\mathrm{mAHP}}\right)$ and the slow afterhyperpolarization current $\left(\mathrm{I}_{\mathrm{SAHP}}\right)$ were measured at 10 and $400 \mathrm{~ms}$ after the completion of the depolarizing pulse, respectively. The hyperpolarization-activated cation current $\left(I_{h}\right)$ was triggered using a 2-s-long hyperpolarizing pulse from $-60 \mathrm{mV}$ to voltages ranging up to $-110 \mathrm{mV}$. The amplitude and kinetics of $\mathrm{I}_{\mathrm{h}}$ were estimated using the TraceFit component of the FitMaster analysis program (HEKA Instruments) during steps to $-90 \mathrm{mV}$. In most cases, two exponential equations were needed to adequately fit $I_{\mathrm{h}}$ traces, and in the current work, we report values corresponding to the faster time constant. Spike frequency adaptation (SFA) was examined using 600-mslong constant current depolarizing steps. For these experiments, we defined the spike frequency adaptation index (Al) as the ratio between the number of spikes in the final $300 \mathrm{~ms}$ of the $600-\mathrm{ms}$ pulse to the number of spikes in the first $300 \mathrm{~ms}$ of the pulse in response to a depolarizing current injection between 500 and 700 pA. Previous studies have quantified spike frequency adaptation by comparing the third and last interspike interval (Hattox and Nelson, 2007; Chen et al., 2008). In the L5 pyramidal neurons of the MPFC, it was the cessation of spiking rather than the interspike interval that was the most notable feature. This feature is not well captured by comparing the third and last interspike interval; hence the current approach to quantifying accommodation. Input resistance was measured using a -200-pA current injection lasting $100 \mathrm{~ms}$. The maximum voltage deflection was used to estimate the cell's approximate input resistance.

All drugs were applied in the bath at the concentration stated in the text. To assess the effects of specific drugs on membrane current, cells were held at $-60 \mathrm{mV}$, and the membrane current was recorded every $6 \mathrm{~s}$, or every $30 \mathrm{~s}$ when also sampling $I_{\text {sAHP. }}$. Drugs were administered only once to each slice unless stated otherwise. When drugs were applied twice to the same slice, at least $10 \mathrm{~min}$ elapsed between applications. Mean current responses to serotonin represent the peak serotonin current with respect to the predrug baseline. All values are presented as mean \pm SEM. Most chemicals were purchased from Sigma-Aldrich or Thermo Fisher Scientific. Tetrodotoxin (TTX) was obtained from Calbiochem-EMD, and apamin and WAY100135, from Tocris. MDL100907 was a gift of Dr. Kenner Rice (NIH/NIDDK).

\section{Cell reconstruction}

Electrodes were filled with intracellular solution supplemented with $0.2 \%-1 \%$ biocytin. In this solution, $\mathrm{KMeSO}_{4}$ was reduced to $119.5 \mathrm{~mm}$ to maintain osmotic balance. After the experiment was completed, the electrode was left in place for a minimum of $20 \mathrm{~min}$ to allow for adequate filling. Slices were then fixed in $4 \%$ paraformaldehyde and refrigerated overnight, washed in PBS, and incubated overnight in streptavidin Alexa Fluor 568 conjugate (1: 1000 , Invitrogen) at $4^{\circ} \mathrm{C}$ with agitation. Slices were then washed three times in PBS and mounted. Filled neurons were imaged with an Olympus FluoView laser scanning confocal microscope equipped with a krypton laser and a $20 \times$ objective. To capture the full extent of the dendritic tree, most neurons were imaged in two partly overlapping stacks of equal depth. These stacks were stitched together using the "stack combiner" plug-in (MacBiophotonics) within ImageJ ( $\mathrm{NIH})$. More than 40 rat cells were filled and imaged, but only 11 of these yielded adequate morphologic reconstruction and the complete set of electrophysiological measurements necessary for analysis. Confocal image stacks from these 11 neurons were used to reconstruct the cells in 3D using Neurolucida (MBF Biosciences). The 3D reconstruction was then analyzed using Neuroexplorer (MBF Biosciences).

\section{Retrograde labeling}

Male Sprague-Dawley rats (P19-P28) were injected with fluorescent latex beads (Retrobeads, LumaFluor) using a 1- $\mu$ l syringe (Hamilton, $7001 \mathrm{KH}$ ). Four different locations were injected: mediodorsal thalamus (MD; 0.6 $\mu$, stereotaxic coordinates, lateral, vertical, anterior/posterior from Bregma in $\mathrm{mm},-2.8,-5.0,0.8)$, dorsal raphe nucleus $(0.5 \mu \mathrm{l},-8.0,-6.2,0.1)$, contralateral cortex (CC; $0.2 \mu \mathrm{l}, 2.0,-2.1,0.5)$, and striatum (Str; $0.4 \mu \mathrm{l},-1.6,4.6$, 4.8). We recorded from striatal projecting cells in both hemispheres (ipsi- and contralateral to the injection site). This approach can be expected to greatly favor recording from intratelencephalic pyramidal cells. Injections were delivered over a 5- to 10-min window using manual control or a microsyringe injector and controller (World Precision Instruments, UMP2 Microsyringe Injector and Micro4 Controller). After the completion of the injection, the syringe needle was left in place for a minimum of $5 \mathrm{~min}$ before being withdrawn slowly. A minimum of $3 \mathrm{~d}$ elapsed between injection and the preparation of acute slices.

\section{Statistical analysis}

Most statistical comparisons between groups used $t$ tests. To generate an unbiased classification of the recorded neurons, a sample of 100 cells was sorted into groups using an unsupervised Bayesian classifier (Autoclass), as implemented in Autoclass@|JM (Achcar et al., 2009). Java Treeview was used to view the data and plot the results (Saldanha, 2004).

\section{Results}

\section{Electrophysiological properties of pyramidal cells of L5 of the rat MPFC}

We recorded from pyramidal neurons of $L 5$ of the anterior cingulate and prelimbic subdivisions of the mPFC in brain slices derived from rats in the fourth and fifth postnatal weeks. As illustrated in Fig. 1, constant current depolarizing steps elicited repetitive spiking exhibiting variable spike frequency adaptation. Previous studies have shown that differences in spike frequency adaptation can be used to distinguish functionally distinct subpopulations of L5 pyramidal cells (Cho et al., 2004; Hattox and Nelson, 2007; Chen et al., 2008; Dembrow et al., 2010; van Aerde and Feldmeyer, 2015). Based on this criterion, most pyramidal cells in this area could be classified into two broad classes, regular spiking neurons with weak adaptation and regular spiking with strong adaptation (Fig. $1 A 1$ and 1B1). We quantified spike frequency 


\section{Weakly adapting pyramidal cell (Type I)}
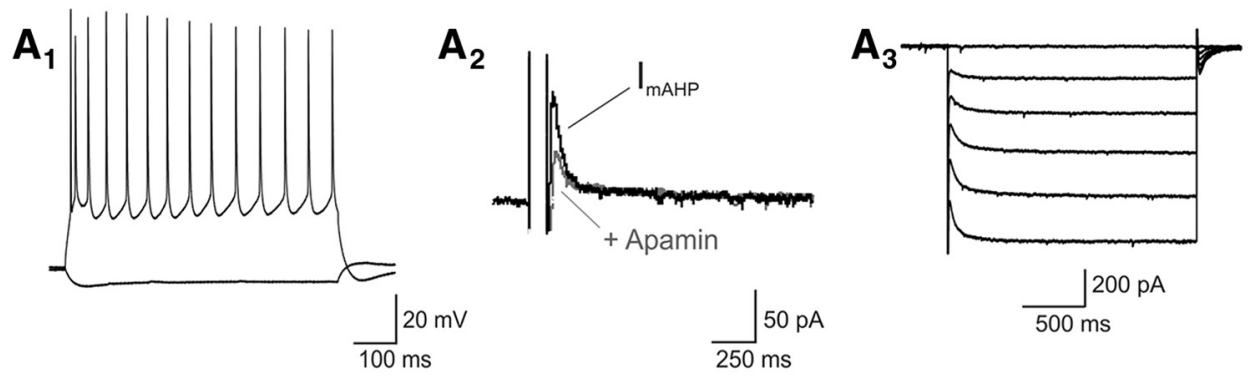

\section{Strongly adapting pyramidal cell (Type II )}
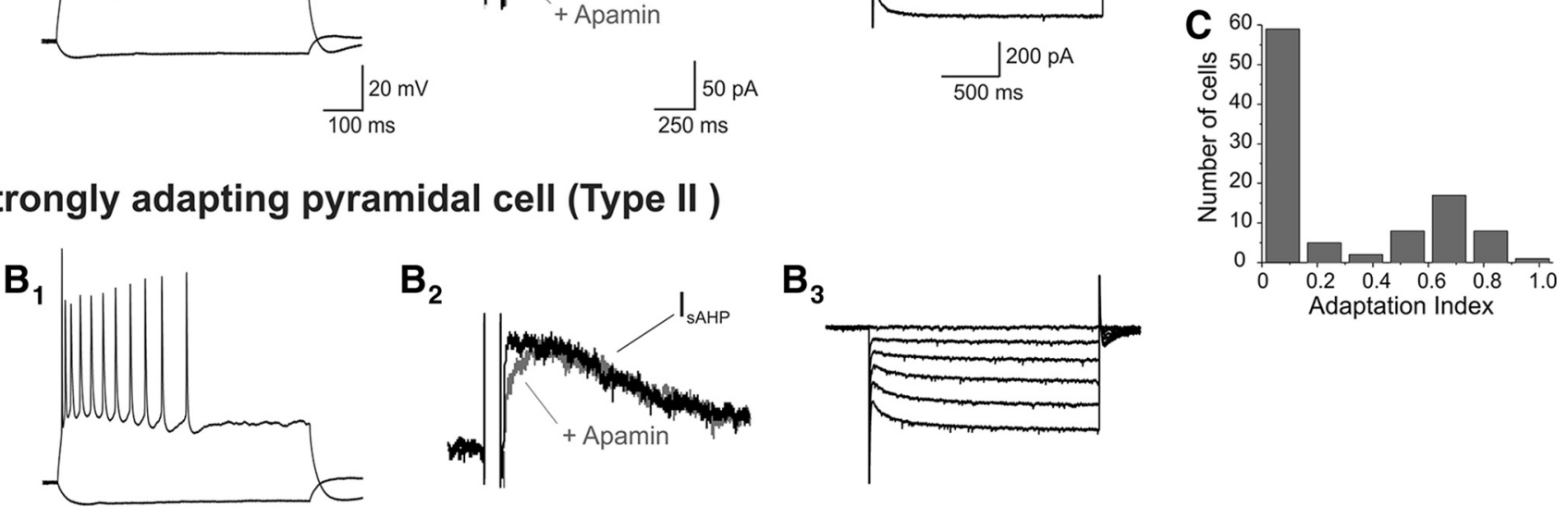

Figure 1. Electrophysiological properties define two pyramidal cell types in L5 of the rat mPFC. One of these corresponds to regular spiking neurons exhibiting limited firing frequency adaptation in response to constant depolarizing current injection $\left(\boldsymbol{A}_{1}\right)$. These cells exhibit a prominent $\mathrm{I}_{\mathrm{mAHP}}$ that is partially inhibited by apamin $\left(100 \mathrm{nM}, \boldsymbol{A}_{2}\right)$ and a relatively fast activating $\mathrm{I}_{\mathrm{h}}\left(\boldsymbol{A}_{3}\right)$ under voltage clamp. We have termed these cells type I, weakly adapting pyramidal cells. The second cell type exhibits strong spike frequency adaptation in response to constant depolarizing current injection $\left(\boldsymbol{B}_{\mathbf{1}}\right)$, a prominent apamin-insensitive $\mathrm{I}_{\mathrm{sAHP}}\left(\boldsymbol{B}_{2}\right)$, and slow-activating $\mathrm{I}_{\mathrm{h}}\left(\boldsymbol{B}_{\mathbf{3}}\right)$. We have termed this second cell type II, strongly adapting pyramidal cells. $\boldsymbol{A}_{2}, \boldsymbol{A}_{\mathbf{3}}, \boldsymbol{B}_{\mathbf{2}}, \boldsymbol{B}_{\mathbf{3}}, \mathrm{Vh}=-60 \mathrm{mV}$. Consistent with this typology, a histogram of spike frequency accommodation characteristics (as defined by the accommodation index) suggests a bimodal distribution (C).

adaptation by comparing the firing in the first and second halves of the depolarizing pulse (adaptation index, Al; see Methods). As illustrated in Fig. $1 C$, a histogram plotting the Al for 100 L5 pyramidal neurons recorded roughly sequentially produced a distribution consistent with the presence of two partly overlapping subpopulations.

Spike frequency adaptation in pyramidal cells is controlled by calcium-activated potassium currents and especially the slow calcium-activated afterhyperpolarization current $\left(I_{\text {SAHP }}\right.$, Madison and Nicoll, 1984; Schwindt et al., $1988,1992)$. Consistent with this view, strongly adapting pyramidal cells expressed a robust $I_{\mathrm{SAHP}}$ when recorded in voltage clamp (Fig. 1B2), whereas weakly adapting neurons generally exhibited little to no $\mathrm{I}_{\text {SAHP }}$ (Fig. 1A2 ). Pyramidal cells express a second, faster calcium-activated potassium current that is carried by apamin-sensitive $\mathrm{K}_{\mathrm{Ca}} 2 . \mathrm{x}-\mathrm{SK}_{\mathrm{Ca}}$ channels (Stocker et al., 1999; Villalobos et al., 2004) and contributes to the apamin-sensitive medium AHP current $\left(I_{\text {mAHP }}\right)$. In contrast to the marked difference in the amplitude of $\mathrm{I}_{\mathrm{SAHP}}$ in strongly adapting and weakly adapting pyramidal cells, administration of apamin identified expression of this second calcium-activated potassium current in both cell types (Fig. 1A2 and 1B2).

During our recordings, we noticed two additional differences that also appeared to distinguish strongly adapting and weakly adapting pyramidal cells in rat mPFC. First, weakly adapting cells tended to have a lower estimated input resistance than strongly adapting cells. Second, the hyperpolarization-activated nonselective cation current $\mathrm{I}_{\mathrm{h}}$ elicited by stepping down from $-60 \mathrm{mV}$ also appeared to differ in these two cell types. Specifically, weakly adapting cells exhibited $\mathrm{I}_{\mathrm{h}}$ currents exhibiting fast activation kinetics (Fig. 1A3), suggesting the involvement of HCN1 subunits (Biel et al., 2009), whereas strongly adapting cells exhibited $I_{h}$ currents with considerably slower activation kinetics (Fig. 1B3).

\section{Sorting of L5 pyramidal cells using a Bayesian classifier}

The qualitative observations above suggested that we could use electrophysiological properties to distinguish two distinct subpopulations of neurons in L5 of the rat $\mathrm{mPFC}$, a view that is consistent with previous findings by others (Dembrow et al., 2010; van Aerde and Feldmeyer, 2015). Therefore we next sought to explore this issue quantitatively. To that effect, we first plotted the Al, the amplitude of $\mathrm{I}_{\mathrm{SAHP}}$, and the time constant for $\mathrm{I}_{\mathrm{h}}$ for a group of $100 \mathrm{~L} 5$ pyramidal cells. As shown in Fig. $2 A$, this plot revealed what appeared to be two distinct clusters of neurons exhibiting little if any overlap in the 3D space defined by these three variables. These results support the idea of that these variables sort two discrete population of pyramidal cells. To quantitatively test this idea, we sorted our sample of L5 pyramidal cells using an unsupervised Bayesian classifier (Autoclass, Achcar et al., 2009) using the amplitude of $I_{\text {sAHP }}$ and the $I_{h}$ activation time constant as sorting variables. This unsupervised classifier determines the most probable number of 
A

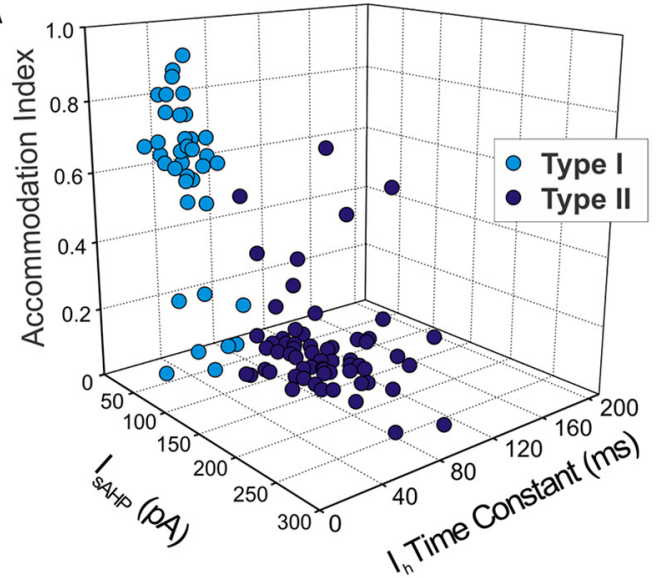

B

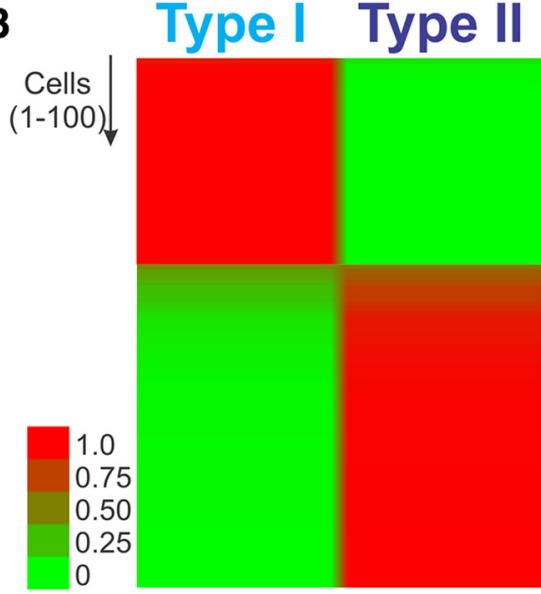

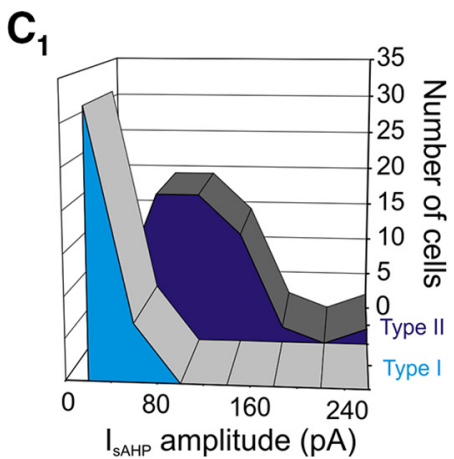

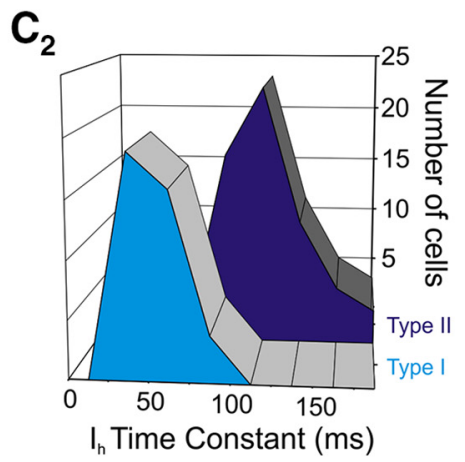

Figure 2. Sorting of L5 pyramidal cells. A, Plotting the amplitude of $\mathrm{I}_{\mathrm{SAHP}}$, the time constant of $\mathrm{I}_{\mathrm{h}}$ and the Al cluster the cells in our sample into what appear to be two largely nonoverlapping subsets. $\boldsymbol{B}$, Autoclass, an unsupervised Bayesian classifier, also sorted the cells in our sample into two classes with the vast majority of cells sorting unambiguously to one of the two classes. The heat map depicts the probability that each cell tested in the current sample belongs to the type I or the type II classes. Probability is color-coded in a green-red scale as indicated in the side bar. After sorting, type I and type II cells, considered as groups, can be seen to differ in terms of the amplitude distribution for $\mathrm{I}_{\mathrm{sAHP}}\left(\boldsymbol{C}_{1}\right)$ and the distribution of time constant for $\mathrm{I}_{\mathrm{h}}\left(\boldsymbol{C}_{2}\right) \cdot \boldsymbol{C}_{\mathbf{1}}-\boldsymbol{C}_{2}: n=100$ cells.

classes (groups) in the data and assigns to each object (cell) the probability of belonging to a given class. Application of this classifier sorted the cells in our sample into two classes that we call type I (weakly adapting) and type II (strongly adapting). The results of this analysis are illustrated in the form of a heat map in Fig. 2B. In this graph each cell is represented by a horizontal line colored to denote, for each cell, the probability of it belonging to the type I and the type II classes, with red corresponding to a high probability and green a low probability. Autoclass unambiguously sorted the vast majority of cells into one of the two classes with very few ambiguous cases (Fig. 2B). To better understand the contributions of $\mathrm{I}_{\mathrm{SAHP}}$ and $\mathrm{I}_{\mathrm{h}}$ to the sorting of these two subpopulations of $L 5$ pyramidal cells, we plotted the amplitude of $I_{\text {SAHP }}$ and the time constant of activation for $\mathrm{I}_{\mathrm{h}}$ for the two cells classes in our sample. As illustrated in Fig. $2 C 1, C 2$, this yields distinct but partly overlapping distributions, emphasizing the importance of both of these parameters for the classification of cells into either of the two cell types.

\section{Effect of serotonin on type I and type II cells}

Previous work has shown that L5 pyramidal cells of the rat $\mathrm{mPFC}$ can also be divided based on their response to serotonin (Beique et al., 2007). Administration of serotonin to the medium-size pyramidal cells of L5 results in small, generally biphasic, changes in membrane potential or holding current (Araneda and Andrade, 1991; Beique et al., 2004, 2007). In contrast, administration of serotonin to the large pyramidal cells of deep L5 results in a strong depolarization/inward current that is often sufficient to initiate sustained spiking (Beique et al., 2007). To examine the relationship between serotonin responsiveness and the two cell types identified above, we administered serotonin $(10 \mu \mathrm{M})$ to 38 type I and 59 type II cells in our sample. As illustrated in Fig. 3, type I cells generally responded to the administration of 5-HT with a strong inward current (Fig. $3 A$ ), whereas type II pyramidal cells generally responded to administration of serotonin with more modest changes in holding current generally involving an outward current that was frequently followed by a smaller inward current (Fig. 3B). Consistent with these observations, a histogram of the initial serotonin responses by cell type displays two distinct, though overlapping, distributions (Fig. 3D).

To better understand the relationship between electrophysiological properties and serotonin responsiveness, we plotted the amplitude of the initial response to sero- 


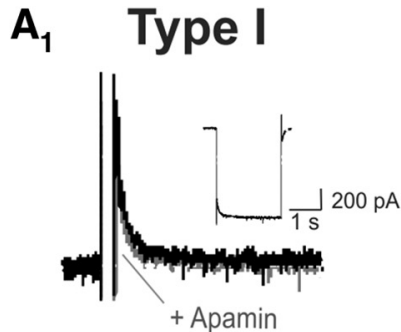

$B_{1} \quad$ Type II

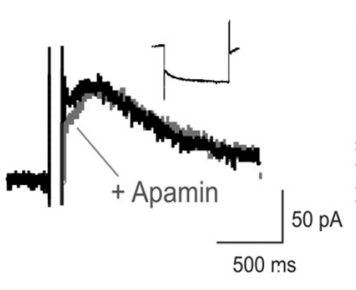

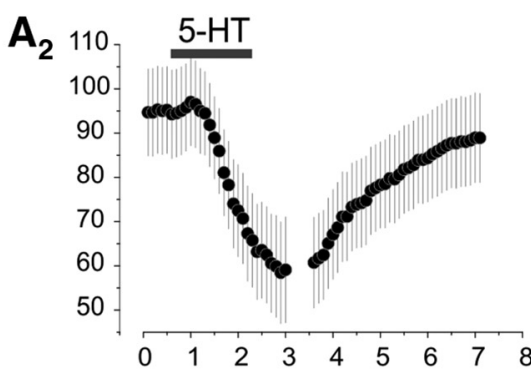

$\mathrm{B}_{2}$

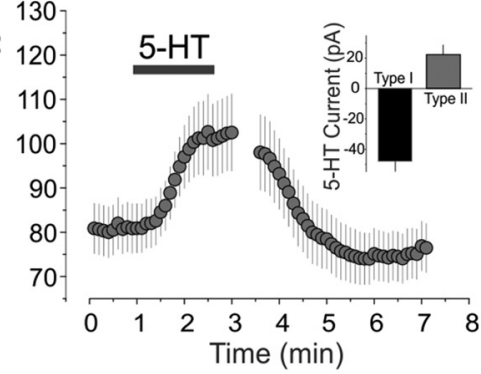

C
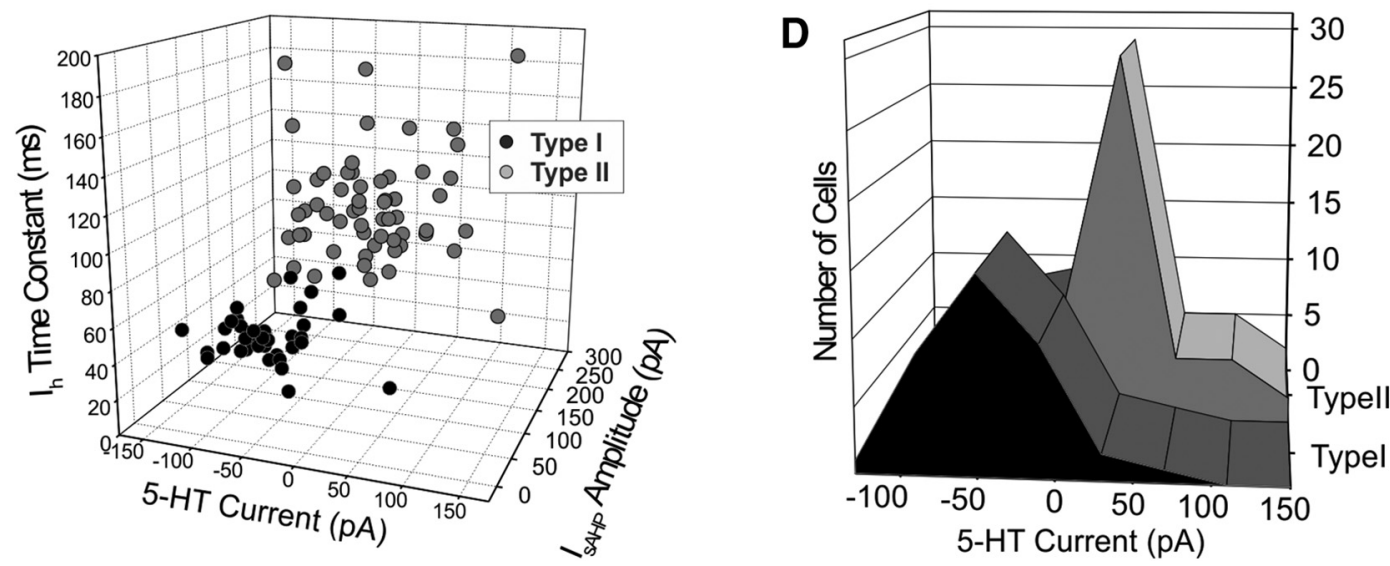

Figure 3. Effect of serotonin on type I and type II pyramidal cells of L5. $\boldsymbol{A}_{1}$, Administration of serotonin (10 $\left.\mu \mathrm{M}\right)$ to an electrophysiologically identified type I pyramidal cell of L5 elicits an inward current that recovers after removal of serotonin from the bath. $A_{2}$, Summary plot illustrating the mean current ( \pm SEM) elicited by serotonin on 38 type I cells of L5. Vh $=-60 \mathrm{mV}$. $\boldsymbol{B}_{\mathbf{1}}, \mathrm{Administration}$ of serotonin $(10 \mu \mathrm{M})$ to an electrophysiologically identified type II cell of L5 elicits an outward current that recovers on removal of serotonin from the bath. $\boldsymbol{B}_{\mathbf{2}}$, Summary plot illustrating the mean current ( \pm SEM) elicited by serotonin on 59 type II cells tested. Vh $=-60 \mathrm{mV}$. Notice that the initial outward current is followed a net inward current as previously reported for many of these cells (Araneda and Andrade, 1991). $\boldsymbol{B}_{\mathbf{2}}$ inset, Bar graph illustrating the peak initial current induced by serotonin. $*, p<0.001$. $\boldsymbol{C}, 3 \mathrm{D}$ plot graphing the time constant of $\mathrm{I}_{\mathrm{h}}$, the amplitude of $\mathrm{I}_{\mathrm{SAHP}}$, and the amplitude of the initial current induced by serotonin in the cell sampled in the current work. $\boldsymbol{D}$, Amplitudes distribution for the initial serotonin-induced current in type I and type II cells.

tonin, the amplitude of $\mathrm{I}_{\mathrm{SAHP}}$, and the activation time constant for $I_{h}$ for all the cells tested with serotonin. As illustrated in Fig. 3C, type I cells form a fairly tight cluster in terms of their electrophysiological properties and serotonin response. In contrast, type II cells form a much looser cluster, suggesting more heterogeneity in this cell population (Fig. 3C).

We next examined the pharmacology of the serotonin response in type I and type II cells. As illustrated in Fig. 4A, two sequential administrations of serotonin to type I pyramidal neurons elicited comparable inward currents, indicating little or no desensitization of the response under our testing conditions. Administration of the $5-\mathrm{HT}_{2 \mathrm{~A}}$ selective antagonist, MDL 100907 (300 nM; Kehne et al.,
1996), immediately after the first application greatly reduced or completely inhibited the serotonin-induced inward current (Fig. $4 A, p<0.01, n=7$ cells). These results indicate that the inward current induced by serotonin in type I pyramidal neurons of $L 5$ is mediated predominantly if not exclusively by activation of receptors of the $5-\mathrm{HT}_{2 \mathrm{~A}}$ subtype. This is consistent with previous findings in the mPFC (Araneda and Andrade, 1991; Zhang, 2003; Beique et al., 2004, 2007; Avesar and Gulledge 2012).

Administration of serotonin to type II pyramidal cells generally resulted in outward currents that, in some cases, were followed by small inward currents. As illustrated in Fig. $4 B$, administration of the selective $5-\mathrm{HT}_{1 \mathrm{~A}}$ receptor antagonist WAY100135 $(3 \mu \mathrm{M})$ completely 
A $_{1} \quad$ Type I pyramidal cells
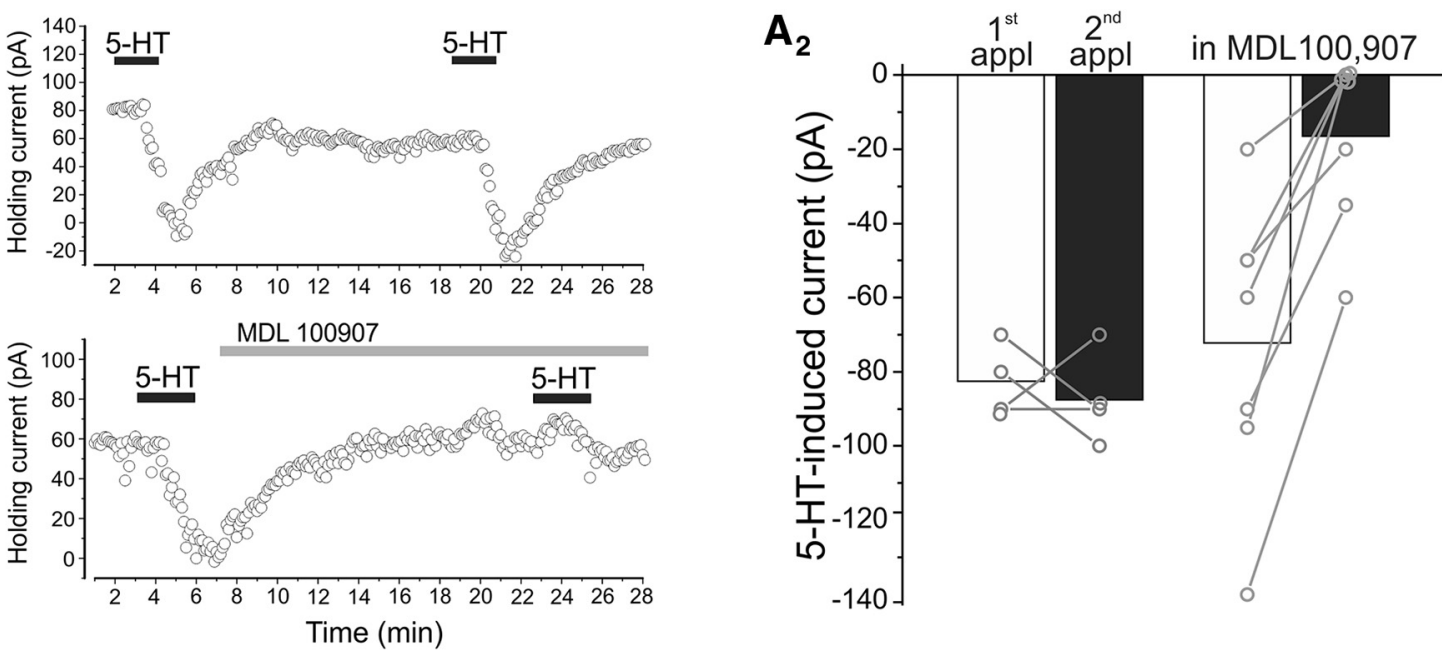

$\mathbf{B}_{1} \quad$ Type II pyramidal cells
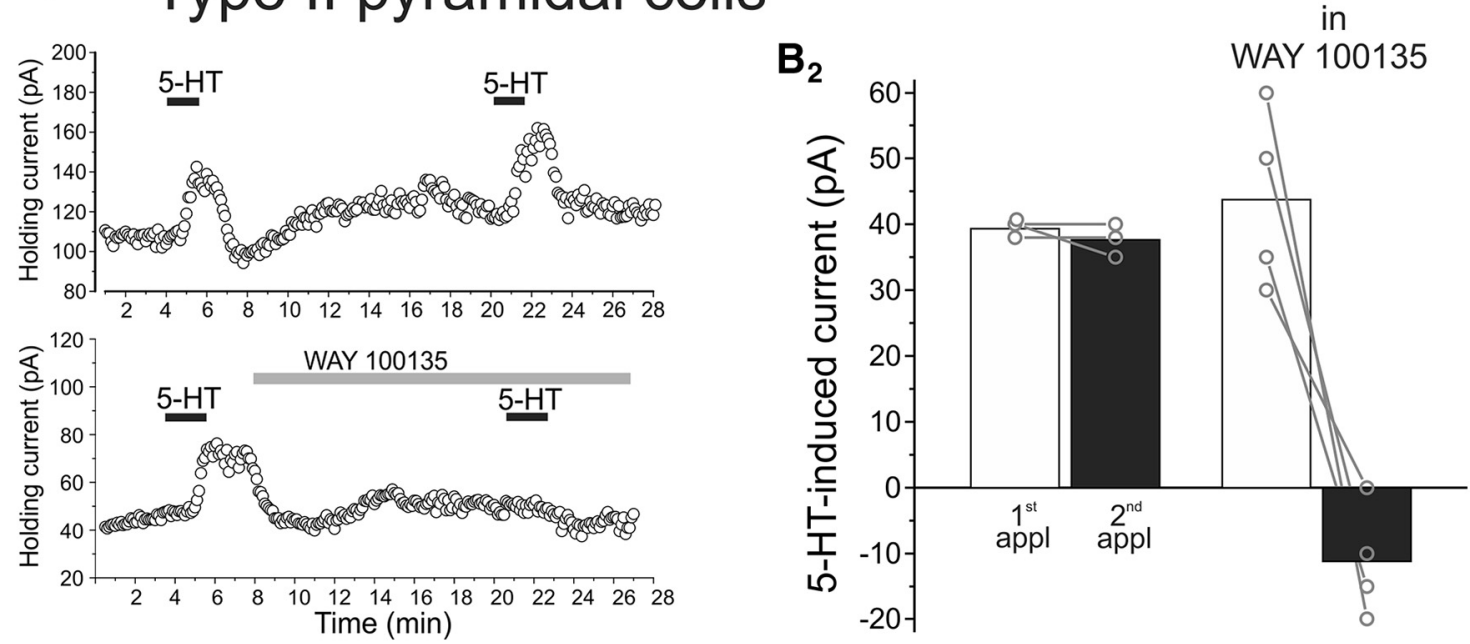

Figure 4. Pharmacology of serotonin responses in type I and type II L5 pyramidal cells of rat mPFC. $\boldsymbol{A}_{\mathbf{1}}$, Top, two consecutive applications of serotonin $(10 \mu \mathrm{M})$ to a type I pyramidal cell results in comparable inward currents indicating minimal desensitization of the response. Bottom, administration of the selective 5- $\mathrm{HT}_{2 \mathrm{~A}}$ receptor antagonist MDL100 907 (300 nM) between serotonin application inhibits the effect of a second serotonin application. $\boldsymbol{A}_{2}$, Summary plot illustrating the effect of MDL100907 on the inward current elicit by serotonin on type I pyramidal cells. $\boldsymbol{B}_{\mathbf{1}}$, Top, two consecutive applications of serotonin (10 $\left.\mu \mathrm{M}\right)$ to a type II pyramidal cell elicit comparable outward currents. Bottom, administration of the selective 5-HT A $_{\text {A }}$ antagonist WAY100135 (3 $\mu \mathrm{M}$ ) between serotonin application blocks the effect of a second application of serotonin. $\boldsymbol{B}_{\mathbf{2}}$, Summary plot illustrating the effect of WAY100135 on the outward current elicited by serotonin in type II pyramidal cells.

blocked the ability of serotonin to elicit the outward current in these cells (first application, $43.75 \pm 6.88 \mathrm{pA}$; second application, $-11.25 \pm 4.27 \mathrm{pA}, p<0.01, n=4)$. In fact, in 3 of the 4 cells tested, a second administration of serotonin in the presence of WAY100135 resulted in a small inward current. These results indicate that the outward current induced by serotonin in type II pyramidal neurons of L5 is mediated by activation of $5-\mathrm{HT}_{1 \mathrm{~A}}$ receptor subtype, but that these cells also coexpress a second serotonin receptor. This second receptor has been reported to be of the $5-\mathrm{HT}_{2 \mathrm{~A}}$ subtype (Araneda and Andrade, 1991).

Previous work in rat mPFC has shown that $5-\mathrm{HT}_{2 \mathrm{~A}}$ receptor activation inhibits $\mathrm{I}_{\mathrm{SAHP}}$ and induces the appear- ance of a $\mathrm{I}_{\mathrm{SADP}}$ (Araneda and Andrade, 1991; Villalobos et al., 2005, 2011; Beique et al., 2007). Consistent with these earlier findings, administration of serotonin (10-30 $\mu \mathrm{M})$ to L5 pyramidal cells displaying type II electrophysiological properties elicited an inhibition of $\mathrm{I}_{\mathrm{SAHP}}$ ( 5 of 5 cells tested, not shown) and the appearance of an $\mathrm{I}_{\text {sADP }}$ ( 4 of 5 cells tested). Similarly, administration of serotonin to L5 pyramidal cells displaying type I electrophysiological properties elicited the appearance of an $\mathrm{I}_{\text {SADP }}$ ( 5 of 5 cells tested). We interpret these results to indicate that the two distinct subpopulations defined by their electrophysiological characteristics broadly correspond to the two distinct subpopulations defined by their serotonin receptor subtype expression. 


\section{Type I and type II cells differ in their axonal projections and dendritic morphology}

As outlined above, pyramidal cells of L5 fall into two major classes, long-range corticofugal and intratelencephalic neurons. To determine if the two cell types identified above in rat slices correspond to these two cell classes, we injected a fluorescent retrograde tracer at four sites known to be projection targets for L5 pyramidal neurons of the PFC (Sesack et al., 1989; Gabbott et al., 2005). We then recorded from retrogradely labeled pyramidal cells in L5 of the prelimbic and anterior cingulate subdivisions of the mPFC. Cells projecting to the thalamus $(n=5$, Fig. $5 A)$ and dorsal raphe $(n=9$, Fig. $5 B)$ displayed the electrophysiological profile of type I pyramidal cells and responded to the administration of serotonin with strong inward currents $(-56.00 \pm 9.27$ and $-66.11 \pm 7.01 \mathrm{pA}$, respectively). In contrast, pyramidal cells projecting to the striatum $(n=9$, Fig. $5 C)$ displayed the electrophysiological profile of type II pyramidal cells and responded to the administration of serotonin with an overall net outward current (Fig. 5C, $22.50 \pm 13.82$ pA). Pyramidal cells projecting to the contralateral PFC (Fig. $5 D$ ) also displayed the electrophysiological characteristics of type II pyramidal cells, but administration of serotonin produced little net current as a result of considerable cell-to-cell variability. We interpret these results to indicate that cells projecting subcortically correspond to type I pyramidal cells, whereas cells projecting to contralateral cortex and striatum (i.e. intratelencephalic pyramidal cells) correspond to type II pyramidal cells.

A number of previous studies have shown that longrange projecting corticofugal neurons and intratelencephalic projecting neurons also differ in terms of their dendritic morphology (e.g. Molnar and Cheung, 2006; Hattox and Nelson, 2007; Dembrow et al., 2010; Avesar and Gulledge, 2012; van Aerde et al., 2015). Therefore, we next examined whether electrophysiologically defined type I and type II cells in the mPFC also differed in terms of their dendritic arborizations. We recorded with biocytin-filled electrodes and tested and reconstructed 11 pyramidal cells, 5 of which were type I and 6 were type II neurons. As illustrated for two representative cells in Fig. $6 A, B$, type I and type II pyramidal neurons displayed distinctly different dendritic arbors. Most strikingly, type I cells exhibited a much larger and complex apical dendritic tree compared to the less extensively branched apical dendrites of type II cells. To quantitatively assess these differences, we conducted a 3D Sholl analysis on the reconstructed cells (Fig. $6 C, D)$. This analysis indicated that type I cells exhibited a significantly greater number of intersections in the outer concentric spheres than type II cells $\left(F_{(1,90),} p<0.0001\right)$. Because such crossings are made by the dendrites of the apical tuft, these results quantitatively confirmed the difference in the apical dendritic tree between these two cell types. The greater complexity of the apical dendrites of type I pyramidal neurons is also evident when plotting the cumulative number of branches as a function of branch order (Fig. 6E). Overall, these results indicate that type I and type II neurons display morphologically distinct apical dendritic trees, with type I pyramidal cells displaying more complex apical dendrites that terminate in a large, extensively branched tuft, whereas type II cells feature apical dendrites with fewer oblique branches and a sparse apical tuft. This provides additional support to the idea that type I cells correspond to long-range corticofugal neurons and type II cells correspond to intratelencephalic L5 pyramidal neurons.

\section{Effects of serotonin on type I and type II cells in mice}

These results outlined above, obtained in rats, differ significantly from those obtained in previous studies by Avesar and Gulledge (2012) and Stephens et al. (2014) using mice. In rats, we find that long-range corticofugal cells express $5-\mathrm{HT}_{2 \mathrm{~A}}$ receptors and are excited by serotonin, while intratelencephalic neurons express $5-\mathrm{HT}_{1 \mathrm{~A}}$ receptors, and secondarily $5-\mathrm{HT}_{2 \mathrm{~A}}$ receptors, which together remodel their excitability. In contrast, Avesar and Gulledge (2012) and Stephens et al. (2014) reported that corticopontine (i.e., long range corticofugal) neurons express predominantly $5-\mathrm{HT}_{1 \mathrm{~A}}$ receptors and are inhibited by serotonin, whereas commissural (i.e. intratelencephalic) cells express $5-\mathrm{HT}_{1 \mathrm{~A}}$ receptors and $5-\mathrm{HT}_{2 \mathrm{~A}}$ receptors and can be excited, inhibited, or express biphasic changes in firing in response to serotonin. To address this apparent discrepancy, we reexamined the effects of serotonin on pyramidal cells of the mPFC in brain slices derived from mice aged P35-P47 ( $n=72$ pyramidal cells in 13 mice). Consistent with findings by others (Hattox and Nelson, 2007), L5 pyramidal cells in mice cortex form a heterogeneous group in terms of spike frequency adaptation as well as $I_{\text {SAHP }}$ and $I_{\mathrm{h}}$ when recorded in voltage clamp (Fig. $7 A)$. As with rats, we used the unsupervised Bayesian clustering algorithm to sort L5 pyramidal neurons into classes. Because $I_{\text {SAHP }}$ was smaller in mice, and appeared to be differentially expressed but still present to some extent in most cells, we used the ratio of $I_{\text {mAHP }}$ and $I_{S A H P}$ amplitudes and the kinetics of $I_{h}$ as sorting variables. As illustrated in the heat map in Fig. 7B, this procedure sorted the recorded neurons into two classes analogous to the type I and type II classes present in rats, with most cells assigned to one class or the other with a high probability.

For the purpose of analyzing the effects of serotonin on these two cell classes, we excluded from the analysis cells that could not be assigned to either class with a probability of at least $90 \%$. This resulted in the exclusion of 6 cells from our sample of 72 neurons. As illustrated in Fig. $7 A, C$, administration of serotonin $(10 \mu \mathrm{M})$ elicited a net outward current in both type I, presumed long-range corticofugal, as well as type II presumed intratelencephalic neurons (38.9 $\pm 5.3 \mathrm{pA}, n=29$, vs. $12.8 \pm 3.7 \mathrm{pA})$. However it is worth noting that we observed considerable cell-to-cell variability, especially among type II cells. The serotonin-induced outward currents were blocked by WAY100135 or WAY100635, indicating that they were mediated by $5-\mathrm{HT}_{1 \mathrm{~A}}$ receptors $(n=11 \mathrm{cells}$ ).

As outlined above, in both rats and mice, activation of $5-\mathrm{HT}_{2 \mathrm{~A}}$ receptors inhibits $\mathrm{I}_{\mathrm{SAHP}}$ and triggers the appearance of a slow $I_{\text {SADP }}$ in pyramidal cells (Araneda and Andrade, 
Thalamus

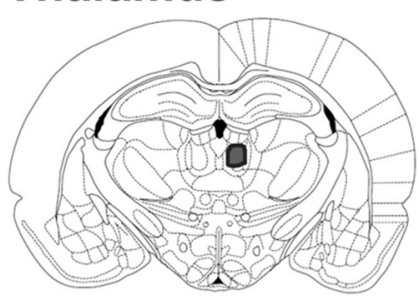

$A_{1}$

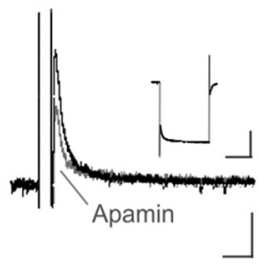

$\mathbf{A}_{2}$

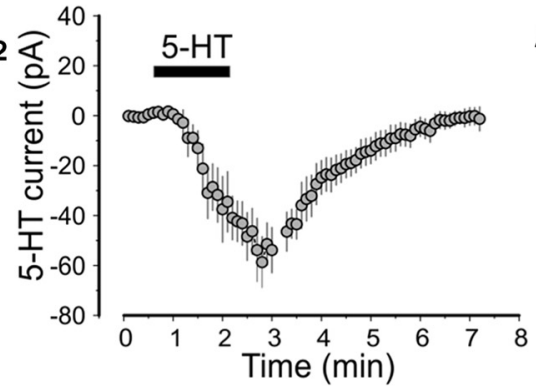

$\mathrm{A}_{3}$

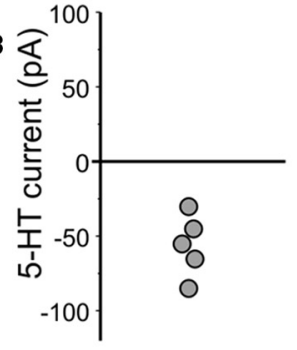

\section{Dorsal Raphe}

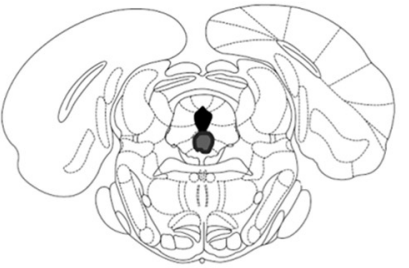

$B_{1}$

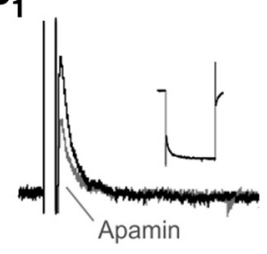

$\mathrm{B}_{2}$

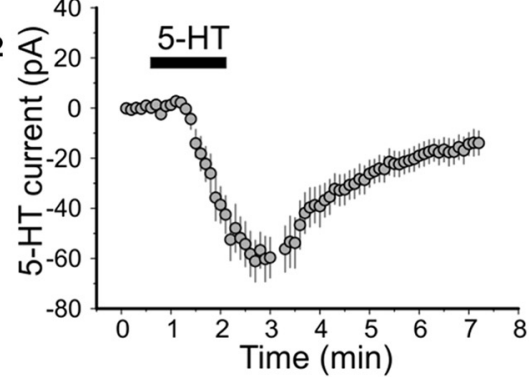

$\mathrm{B}_{3}$

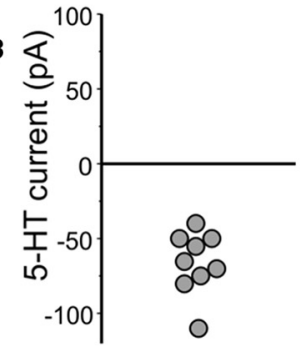

\section{Striatum}

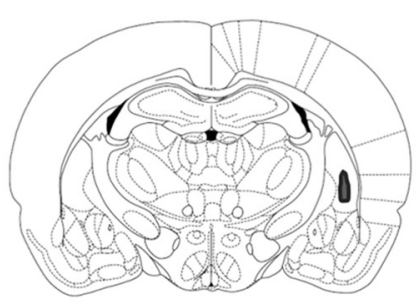

$\mathrm{C}_{1}$

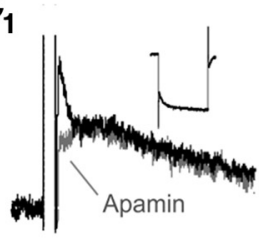

$\mathrm{C}_{2}$

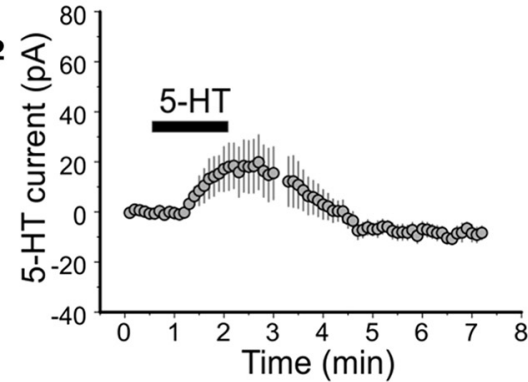

$\mathrm{C}_{3}$

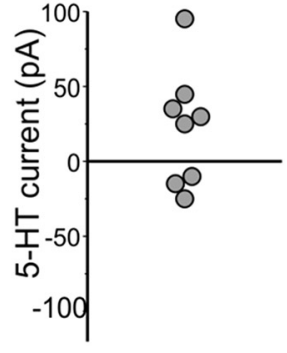

\section{Contralateral PFC}

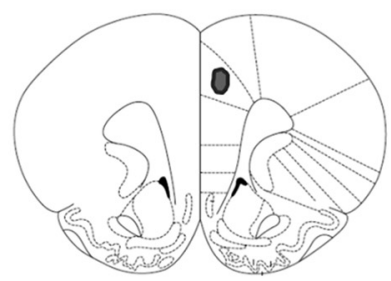

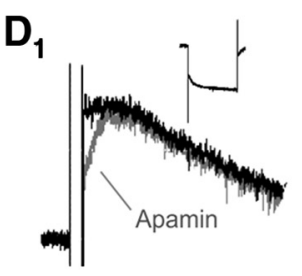
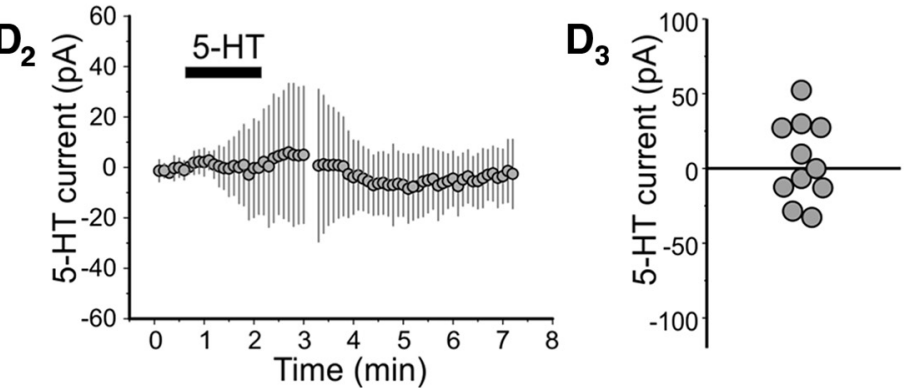

Figure 5. Effect of serotonin on retrogradely labeled L5 pyramidal neurons. Thalamus. $\boldsymbol{A}_{\mathbf{1}}, \mathrm{I}_{\mathrm{sAHP}}$ and $\mathrm{I}_{\mathrm{h}}$ recorded from a L5 neuron retrogradely labeled from the thalamus. I scale: 200 pA, 1 s. I sAHP scale: 50 pA, 250 ms. The scale applies to panels $\boldsymbol{A}_{1}-\boldsymbol{D}_{\mathbf{1}}$. $\boldsymbol{A}_{\mathbf{2}}$, Summary plot illustrating the mean current ( \pm SEM) elicited by serotonin (10 $\mu \mathrm{M})$ in neurons retrogradely labeled from the thalamus ( $n=5$ cells). $\boldsymbol{A}_{3}$, Graph illustrating the peak serotonin current recorded in these cells. Dorsal raphe. $\boldsymbol{B}_{1}, I_{\mathrm{sAHP}}$ and $\mathrm{I}_{\mathrm{h}}$ recorded from a L5 neuron retrogradely labeled from the dorsal raphe. $\boldsymbol{B}_{2}$, Summary plot illustrating the mean current ( \pm SEM) elicited by serotonin $(10 \mu \mathrm{M})$ in neurons retrogradely labeled from the dorsal raphe $\left(n=9\right.$ cells). $\boldsymbol{B}_{\mathbf{3}}$, Graph illustrating the peak serotonin current recorded in these cells. Striatum. $\boldsymbol{C}_{1}, I_{S A H P}$ and $I_{h}$ recorded from a L5 neuron retrogradely labeled from the striatum. $\boldsymbol{C}_{2}$, Summary plot illustrating the mean current ( \pm SEM) elicited by serotonin $(10 \mu \mathrm{M})$ in neurons retrogradely labeled from the striatum $\left(n=8\right.$ cells). $\boldsymbol{C}_{3}$, Graph illustrating the peak serotonin current recorded in these cells. Contralateral PFC. $\boldsymbol{D}_{1}, \mathrm{I}_{\mathrm{SAHP}}$ and $\mathrm{I}_{\mathrm{h}}$ recorded from a L5 neuron retrogradely labeled from the contralateral PFC. $\boldsymbol{D}_{2}$, Summary plot illustrating the mean current $( \pm$ SEM) elicited by serotonin $(10 \mu \mathrm{M})$ in neurons retrogradely labeled from the contralateral PFC $\left(n=11\right.$ cells). $\boldsymbol{D}_{3}$, Graph illustrating the peak serotonin current recorded in these cells. The cells illustrated in panels $\boldsymbol{A}-\boldsymbol{D}$ were assigned a probability of at least $95 \%$ for belonging to the type I class $(\boldsymbol{A}$ and $\boldsymbol{B})$ or the type II class $(\boldsymbol{C}$ and $\boldsymbol{D})$ by the Bayesian classifier. 
A

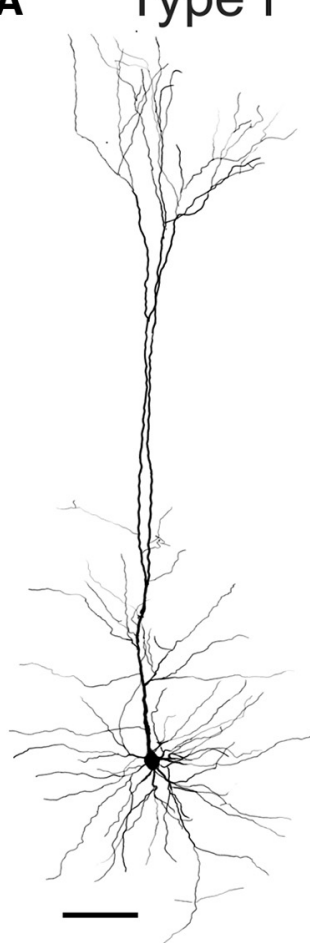

C

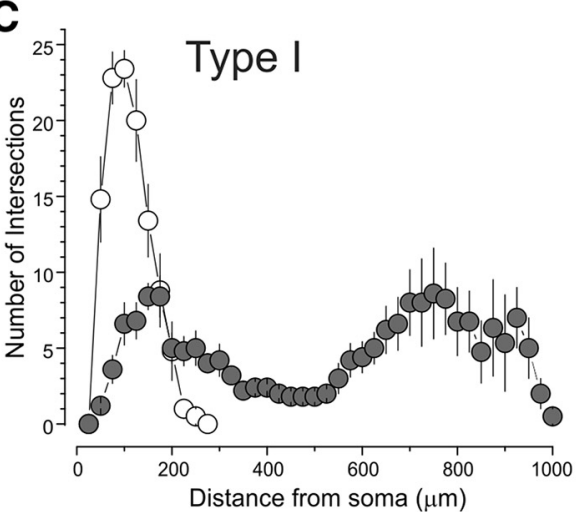

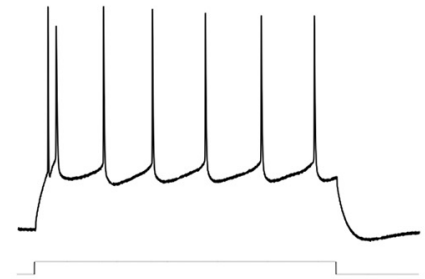
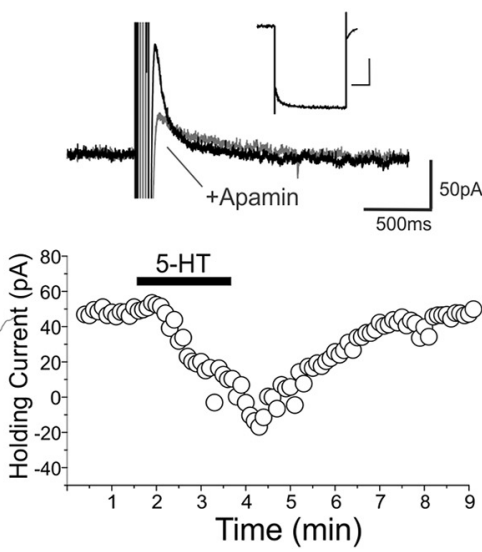

D

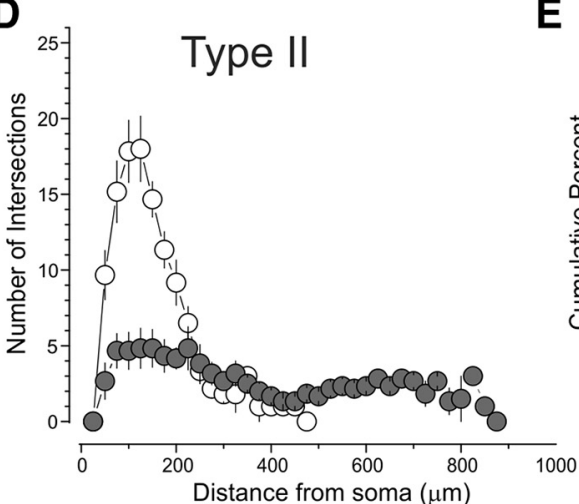

E
B Type II
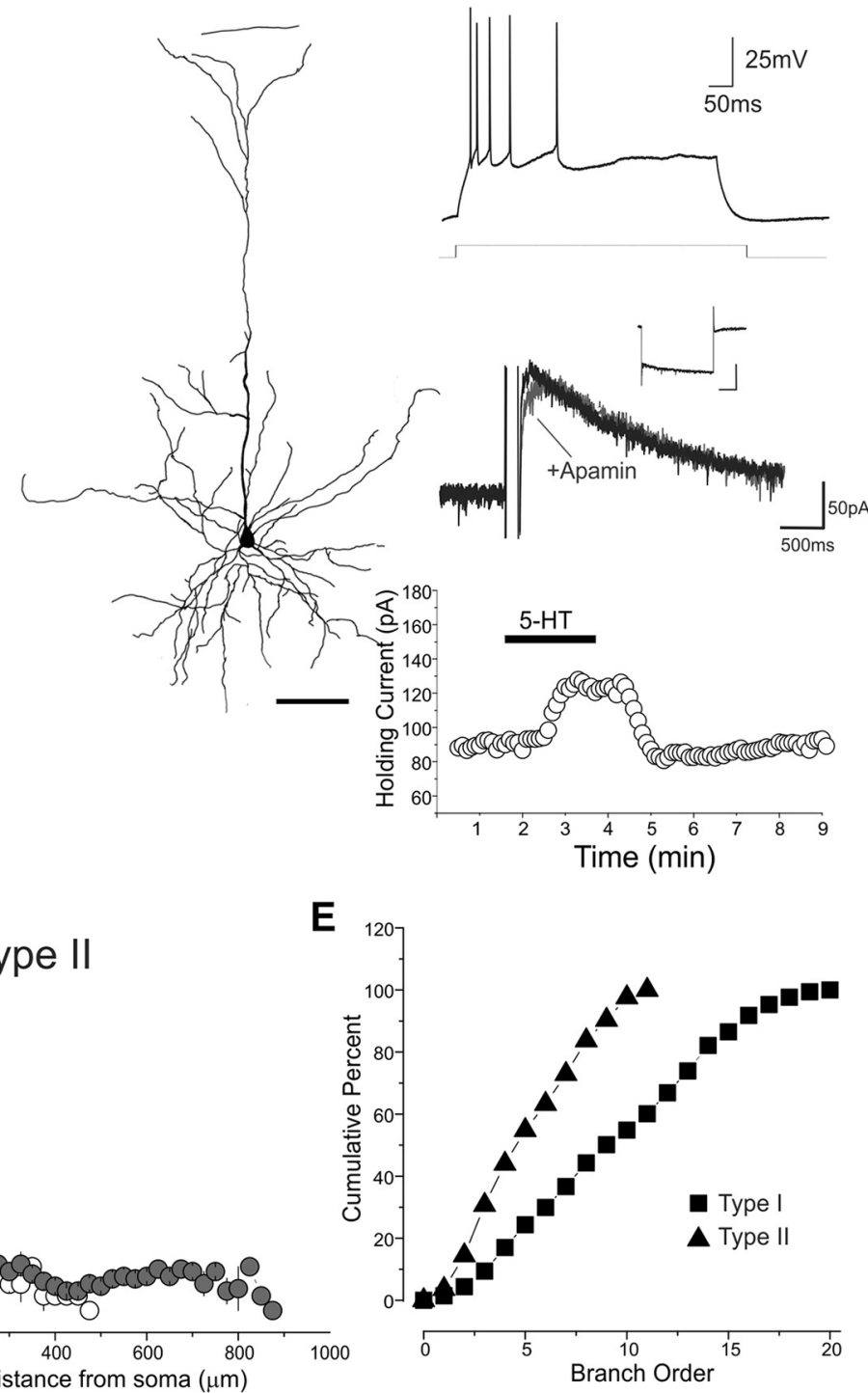

Figure 6. Neuronal morphology of type I and type II neurons. A, Reconstruction of an electrophysiological and pharmacologically identified type I neuron. Neuron reconstruction scale: $100 \mu \mathrm{m}, I_{\mathrm{h}}$ inset scale, $500 \mathrm{~ms}, 200 \mathrm{pA}$. B, Reconstruction of an electrophysiological and pharmacologically identified type II neuron. Neuron reconstruction scale: $100 \mu \mathrm{m}, \mathrm{I}_{\mathrm{h}}$ inset scale, $500 \mathrm{~ms}, 200 \mathrm{pA}$. $\boldsymbol{C}, \boldsymbol{D}$, Scholl plots for the apical (filled circle) and basal (hollow circles) dendrites. Error bars depict the SEM. Branch order cumulative histogram for type I and type II pyramidal cells of L5. Panels $\boldsymbol{C}-\boldsymbol{E}$ depict results derived from 5 type I and 7 type II neurons.

1991; Villalobos et al., 2005). In the current sample, administration of serotonin elicited the inhibition of $\mathrm{I}_{\mathrm{SAHP}}$, often accompanied by its replacement by $I_{\text {SADP }}$, in 18 of 28 type I cells and 28 of 29 type II cells tested (Fig $7 D$ ). This suggests that $5-\mathrm{HT}_{1 \mathrm{~A}}$ and $5-\mathrm{HT}_{2 \mathrm{~A}}$ receptors are most likely coexpressed by both cell types in mice, although clearly $5-\mathrm{HT}_{1 \mathrm{~A}}$ receptors predominate in long-range corticofugal cells. This interpretation is broadly consistent with previous reports (Avesar and Gulledge, 2012; Stephens et al., 2014).

\section{Effects of serotonin on mice L5 pyramidal cells during development}

Previous studies in rats have shown that serotonin depolarizes and excites L5 pyramidal cells during the first
2 postnatal weeks (Zhang, 2003; Beique et al., 2004). Although these earlier studies did not distinguish between long-range corticofugal and intratelencephalic neurons, the invariant depolarization and excitation observed suggests this effect is common to both cell classes. Are the effects of serotonin on mice L5 pyramidal cells also developmentally regulated? To address this question, we recorded from $161 \mathrm{~L} 5$ pyramidal cells of the $\mathrm{mPFC}$ during the first postnatal month (P7-P26). During the early postnatal period, most if not all pyramidal neurons of L5 exhibit a large $I_{h}$ with slow activation kinetics. This $I_{h}$ does not appear qualitatively or quantitatively continuous with those seen at later developmental stages. This made it difficult to assign these cells to either of the cell types 
A $\quad$ Type I - mouse
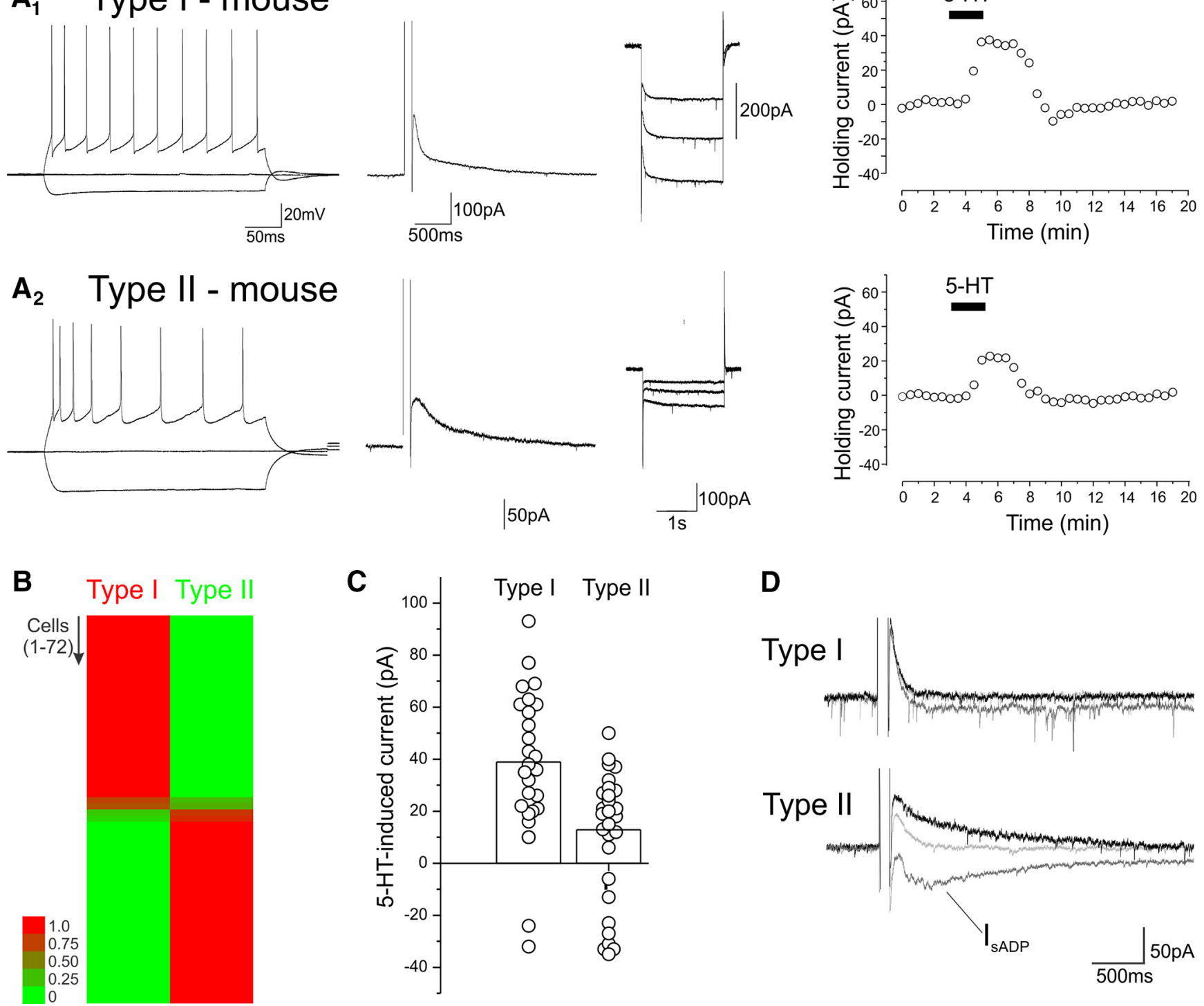

Figure 7. Type I and type II cells in L5 of the mouse mPFC. $\boldsymbol{A}_{\mathbf{1}}, \boldsymbol{A}_{\mathbf{2}}$, Electrophysiological characterization and response to serotonin administration $(10 \mu \mathrm{M})$ in two L5 pyramidal cells, one classified as a type I and the other as type II by the Bayesian sorter. $\boldsymbol{B}$, Heat map depicting the probability that each of the 72 cells tested belongs to the type I and type II classes as determined by Autoclass. The probability for each cell is color-coded as depicted in the scale bar. $\boldsymbol{C}$, Summary graph plotting the amplitude of the peak serotonin-induced currents in the cells sampled. $\boldsymbol{D}$, Effect of serotonin on $\mathrm{I}_{\mathrm{SAHP}}$ and $\mathrm{I}_{\text {SADP }}$ in type I and type II cells. Traces were baseline subtracted for clarity. The type I cell responded to serotonin with a 69-pA outward current and the type II cell with a-24-pA inward current. Overall, in this group of cells, serotonin $(10-30 \mu \mathrm{m})$ elicited a $-14 \pm 6.5-p A$ inward shift in the aftercurrent in type I cells and $-27 \pm 3.5 \mathrm{pA}$ in type II cells $(p<0.01)$.

using the criteria used for older animals. Therefore we analyzed L5 cells as a single group.

Fig. 8 illustrates the peak amplitude of the serotonininduced current during the first postnatal month. As originally seen in rats, the response to serotonin depended on the age of the mouse. Bath administration of serotonin (30 $\mu \mathrm{M}, 1 \mathrm{~min}$ ) triggered no effect or an inward current in slices derived from young pups (P7-P12). However, this effect progressively switched to an outward current at the end of the second week (Fig. 8), which then increased in amplitude to reach adult levels by P26. Interestingly, between P7 and P11, we could not detect any effect of serotonin in a large fraction of the L5 pyramidal neurons tested, an observation that contrasts with the more widespread effect of serotonin on L5 pyramidal neurons in rats (12 responders of 12 cells tested in the current study, inward current: $-40.00 \pm 8.68$ $\mathrm{pA}$, mean \pm SEM). Thus there are similarities but also some significant differences in the trajectory of serotonin responses in rats and mice during development.

\section{Discussion}

In the present work, we have investigated the effects of serotonin on the excitability of pyramidal cells of L5 in the rat and mouse mPFC. Rat L5 pyramidal cells of this region can be sorted into two main classes corresponding to longrange corticofugal and intratelencephalic neurons. We show that serotonin elicits a $5-\mathrm{HT}_{2 \mathrm{~A}}$ receptor-mediated inward (depolarizing) current in long-range corticofugal cells, while it 


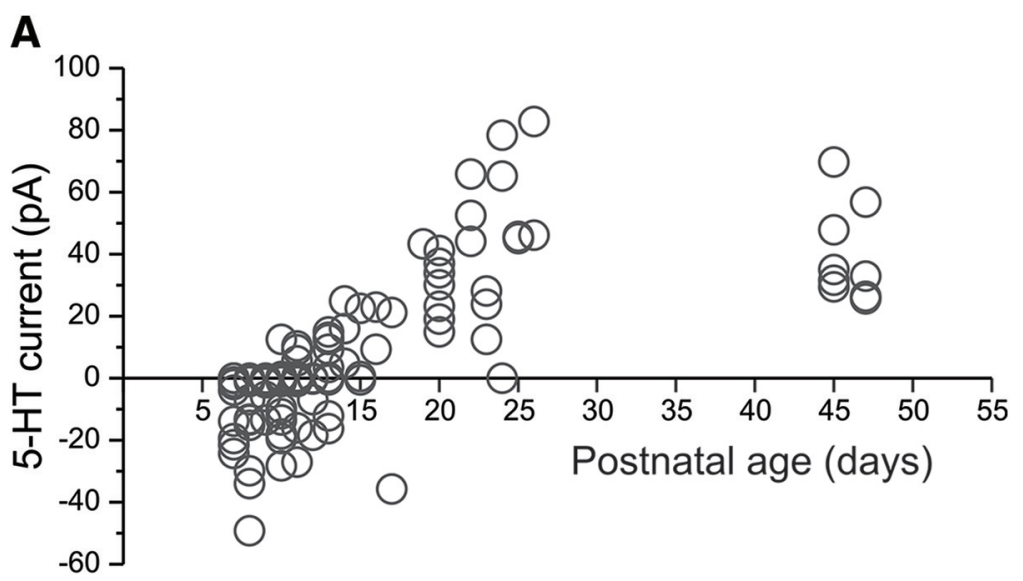

B
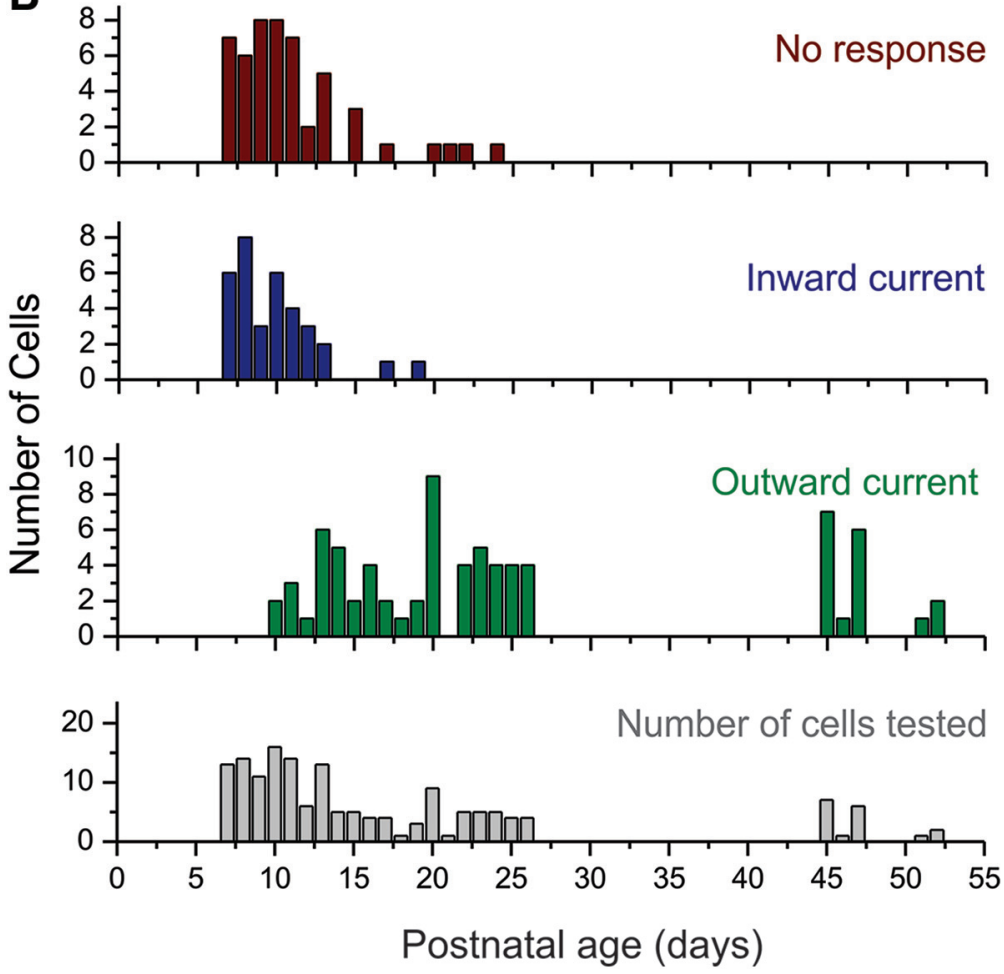

Figure 8. Effects of serotonin on mouse L5 pyramidal neurons during the early postnatal period. $\boldsymbol{A}$, Graph plotting the peak initial current elicited by serotonin on pyramidal cells of L5 as a function of postnatal age. $\boldsymbol{B}$, Histograms depicting the number of cells exhibiting no response, an inward current, and outward current as a function of postnatal age, as well as the number of cells tested at each age.

elicits a more variable response dominated by a $5-\mathrm{HT}_{1 \mathrm{~A}}$ receptor-mediated (hyperpolarizing) outward current in intratelencephalic L5 neurons. We then show that these effects contrast with those seen in mice where serotonin responses in presumed long-range corticofugal as well as intratelencephalic $L 5$ pyramidal cells are dominated by a $5-\mathrm{HT}_{1 \mathrm{~A}}$ receptor-mediated (hyperpolarizing/inhibitory) outward current. Finally we show that serotonin responses in L5 of the mouse mPFC are developmentally regulated with $5-\mathrm{HT}_{1 \mathrm{~A}}$ receptor-mediated outward currents not emerging until the end of the second postnatal week.

It has long been recognized that L5 is heterogeneous and contains two classes of neurons, intratelencephalic neurons that project within the telencephalon and longrange corticofugal cells that project to distal subcortical targets (Koester and O'Leary, 1993; Molnar and Cheung, 2006). More recent studies have shown that these two cell classes differ in terms of their developmental origin (Molyneaux et al., 2007; Leone et al., 2008) and their adult electrophysiological properties (Christophe et al., 2005; Hattox and Nelson, 2007; Dembrow et al., 2010; Groh et al., 2010; Avesar and Gulledge, 2012; Gee et al., 2012; van Aerde et al., 2015). In current clamp recordings, long-range corticofugal and intratelencephalic neurons can be seen to differ in terms of their spike frequency adaptation and the presence of a voltage sag in response 
to constant hyperpolarizing current injection. In the current work, we used an unsupervised Bayesian classifier to sort a sample of a hundred L5 pyramidal neurons based on the amplitude of $\mathrm{I}_{\mathrm{SAHP}}$, a major contributor to spike frequency adaptation, and the time constant of $I_{h}$, since the voltage sag would be most pronounced in cells expressing a fast $I_{h}$. This classifier yielded two cell classes that we have called type I and type II pyramidal cells. Retrograde labeling and neuronal reconstructions confirmed that these two cell classes correspond to long-range corticofugal and intratelencephalic neurons, respectively. Overall, these results and classification are broadly consistent with previous work on L5 of the rat mPFC (Dembrow et al., 2010; van Aerde and Feldmeyer, 2015), although the robust sorting obtained using $I_{\text {SAHP }}$ and $I_{h}$ was unexpected.

Previous studies have shown that many pyramidal cells of $\mathrm{L} 5$ coexpress $5-\mathrm{HT}_{1 \mathrm{~A}}$ and $5-\mathrm{HT}_{2 \mathrm{~A}}$ receptors in the mPFC. Activation of the $5-\mathrm{HT}_{1 \mathrm{~A}}$ receptors in these cells elicits a hyperpolarization/outward current, while the activation of the coexpressed $5-\mathrm{HT}_{2 \mathrm{~A}}$ receptors elicits a delayed depolarization/inward current and the inhibition of the sAHP/I $\mathrm{I}_{\text {SAHP }}$ (Araneda and Andrade, 1991). The coactivation of these two receptors by serotonin effectively remodels the integrative properties of these cells (Araneda and Andrade, 1991). Although these cells represent the most common cell type in L5, more recent work has identified a second population of cells in this area that appears to express solely $5-\mathrm{HT}_{2 \mathrm{~A}}$ receptors and is strongly excited by serotonin (Beique et al., 2007). In the current work, we show that the first of these cell types, which we call type II, corresponds to intratelencephalic neurons, and the second cell type, which we call type I, corresponds to long-range corticofugal pyramidal cells. These findings add to the growing appreciation of the differential effects of serotonin on pyramidal cell subtypes, an idea that can be traced to the prescient work by Spain in cat motor cortex $>20$ years ago (Spain, 1994). They also add to a growing literature documenting the differential regulation of long-range corticofugal and intratelencephalic L5 pyramidal cell types by neuromodulators (Shepherd, 2013).

The results outlined above, obtained in rats, differ dramatically from those obtained in mice by Gulledge and colleagues (Avesar and Gulledge, 2012; Stephens et al., 2014), who reported $5-\mathrm{HT}_{2 \mathrm{~A}}$ receptor-mediated excitations in commissural (i.e., intratelencephalic) neurons and $5-\mathrm{HT}_{1 \mathrm{~A}}$ receptor-mediated hyperpolarizations in both commissural and cortico-pontine (i.e., long-range corticofugal) pyramidal cells. To explore this discrepancy, we conducted recordings in L 5 of the mouse mPFC under conditions identical to those we used in rats. We could again distinguish two electrophysiological cell types analogous to those present in rats that we interpret to correspond to intratelencephalic and long-range corticofugal neurons. Remarkably, we could confirm that in mice, $5-\mathrm{HT}_{1 \mathrm{~A}}$ and $5-\mathrm{HT}_{2 \mathrm{~A}}$ receptors are coexpressed in both cell types, with $5-\mathrm{HT}_{1 \mathrm{~A}}$ receptor-mediated responses predominating in long-range corticofugal cells and $5-\mathrm{HT}_{2 \mathrm{~A}}$ receptor-mediated depolarizations being vastly more robust in intratelencephalic neurons. This indicates that the effect of serotonin on long-range corticofugal cells is essentially reversed in rats and mice; a predominant $5-\mathrm{HT}_{2 \mathrm{~A}}$ receptor-mediated depolarization/inward current in rats and a predominant $5-\mathrm{HT}_{1 \mathrm{~A}}$ receptor-mediated hyperpolarization/outward current in mice.

In contrast, the work of our labs converges to demonstrate that the effect of serotonin on intratelencephalic neurons is similar in rat and mice and involves the coactivation of $5-\mathrm{HT}_{1 \mathrm{~A}}$ and $5-\mathrm{HT}_{2 \mathrm{~A}}$ receptors. Thus our work indicates that $5-\mathrm{HT}_{2 \mathrm{~A}}$ receptors are broadly expressed in rat and mouse L5 intratelencephalic neurons, where they increase membrane excitability by targeting multiple ion currents (Araneda and Andrade, 1991; Villalobos et al., 2005, and current work). Similarly, work by the Gulledge lab has shown broad expression of the predicted $5-\mathrm{HT}_{2 \mathrm{~A}}$ receptor-mediated activity-dependent excitations in mouse L5 intratelencephalic neurons of the MPFC (Avesar and Gulledge, 2012; Stephens et al., 2014). Similarly, both labs also concur in observing robust $5-\mathrm{HT}_{1 \mathrm{~A}}$ responses in these same cells, although our work suggests a somewhat higher prevalence of such responses. This modest quantitative discrepancy could reflect our reliance on measurements of individual membrane currents to assess receptor expression compared with the more integrative approach of examining firing rate. Alternatively, it could reflect differences in the animal strain used, how we define L5 in the slice, or even differences in our recording conditions.

Previous studies in rat have shown a strong developmental regulation of the effects of serotonin in the immediate postnatal period. Specifically serotonin broadly excites rat L5 pyramidal cells after birth, and it is not until the third postnatal week, after opening of the eyes, that the intratelencephalic neurons begin to express serotonin-induced $5-\mathrm{HT}_{1 \mathrm{~A}}$ receptor-mediated inhibitory responses (Zhang, 2003; Beique et al., 2004). Here we show a similar developmental regulation of serotonin responses in pyramidal cells of L5 of the mouse mPFC. As in rats, serotonin elicits predominantly excitatory responses during the early postnatal period, and $5-\mathrm{HT}_{1 \mathrm{~A}}$ receptor-mediated hyperpolarizing responses do not begin to appear until the second postnatal week. The main difference between rats and mice is the presence of a large proportion of L5 pyramidal cells that appears unresponsive to serotonin during early postnatal development. During these experiments, we considered the possibility that these nonresponsive cells may represent long-range corticofugal neurons. Unfortunately, it was difficult to identify immature intratelencephalic from long-range corticofugal cells based on their electrophysiological properties. Therefore we could not readily test for differences in the developmental trajectory of these two cell classes.

The results outlined above clarify how serotonin regulates the output of the mPFC. In both rats and mice, serotonin regulates intratelencephalic $L 5$ output by activating $5-\mathrm{HT}_{1 \mathrm{~A}}$ and $5-\mathrm{HT}_{2 \mathrm{~A}}$ receptors which, when coactivated on single neurons, modulate the input-output relationship of these cells (Araneda and Andrade, 1991). Serotonin also regulates the long-range subcortical output of $\mathrm{L} 5$ neurons but appears to do so differently in rats and mice. In rats, serotonin acts via $5-\mathrm{HT}_{2 \mathrm{~A}}$ receptors to 
facilitate the output of cortex via L5 long-range projecting corticofugal cells, whereas in mice it acts via $5-\mathrm{HT}_{1 \mathrm{~A}}$ receptors to inhibit this output. This opposite effect of serotonin on L5 output in rat and mouse was unanticipated. It is possible, perhaps even probable, that this difference may be rooted in as yet unrecognized ethological differences between these two rodent species. In other words, this may represent a real species difference. Alternatively, because the rats in our experiments were purchased from a vendor while the mice were bred inhouse, it is also possible that this difference could reflect their divergent developmental histories. Early stress, for example, has been shown to greatly facilitate $5-\mathrm{HT}_{2 \mathrm{~A}}$ receptor function in the rat mPFC (Benekareddy et al., 2010). Additional studies will be needed to distinguish between these possibilities.

\section{References}

Achcar F, Camadro JM, Mestivier D (2009) AutoClass@IJM: a powerful tool for Bayesian classification of heterogeneous data in biology. Nucleic Acids Res 37:W63-W67. CrossRef Medline

Andrade R (2011) Serotonergic regulation of neuronal excitability in the prefrontal cortex. Neuropharmacology 61:382-386. CrossRef Medline

Andrade R, Beck SG (2010) Cellular effects of serotonin in the CNS. In: Handbook of the Behavioral Neurobiology of Serotonin, First Edition (Muller CP, Jacobs BL, eds), pp. 219-231. London: Academic Press/Elsevier.

Araneda R, Andrade R (1991) 5-Hydroxytryptamine2 and 5-hydroxytryptamine $1 \mathrm{~A}$ receptors mediate opposing responses on membrane excitability in rat association cortex. Neuroscience 40:399412. Medline

Avesar D, Gulledge AT (2012) Selective serotonergic excitation of callosal projection neurons. Front Neural Circuits 6:12. CrossRef Medline

Bang SJ, Jensen P, Dymecki SM, Commons KG (2012) Projections and interconnections of genetically defined serotonin neurons in mice. Eur J Neurosci 35:85-96. CrossRef Medline

Beique JC, Imad M, Mladenovic L, Gingrich JA, Andrade R (2007) Mechanism of the 5-hydroxytryptamine $2 \mathrm{~A}$ receptor-mediated facilitation of synaptic activity in prefrontal cortex. Proc Natl Acad Sci U S A 104:9870-9875. CrossRef Medline

Beique JC, Campbell B, Perring P, Hamblin MW, Walker P, Mladenovic L, Andrade R (2004) Serotonergic regulation of membrane potential in developing rat prefrontal cortex: coordinated expression of 5-hydroxytryptamine (5-HT)1A, 5-HT2A, and 5-HT7 receptors. J Neurosci 24:4807-4817. CrossRef Medline

Biel M, Wahl-Schott C, Michalakis S, Zong X (2009) Hyperpolarization-activated cation channels: from genes to function. Physiol Rev 89:847-885. CrossRef Medline

Benekareddy M, Goodfellow NM, Lambe EK, Vaidya V (2010) Enhanced function of prefrontal serotonin $5-\mathrm{HT}_{2}$ receptors in a rat model of psychiatric vulnerability. J Neurosci 30:12138-12150. CrossRef Medline

Chen B, Wang SS, Hattox AM, Rayburn H, Nelson SB, McConnell SK (2008) The Fezf2-Ctip2 genetic pathway regulates the fate choice of subcortical projection neurons in the developing cerebral cortex. Proc Natl Acad Sci U S A 105:11382-11387. CrossRef Medline

Cho RH, Segawa S, Mizuno A, Kaneko T (2004) Intracellularly labeled pyramidal neurons in the cortical areas projecting to the spinal cord. I. Electrophysiological properties of pyramidal neurons. Neurosci Res 50:381-394. CrossRef Medline

Christophe E, Doerflinger N, Lavery DJ, Molnár Z, Charpak S, Audinat $E$ (2005) Two populations of layer $v$ pyramidal cells of the mouse neocortex: development and sensitivity to anesthetics. J Neurophysiol 94:3357-3367. CrossRef Medline
Dembrow NC, Chitwood RA, Johnston D (2010) Projection-specific neuromodulation of medial prefrontal cortex neurons. J Neurosci 30:16922-16937. CrossRef Medline

Gabbott PL, Warner TA, Jays PR, Salway P, Busby SJ (2005) Prefrontal cortex in the rat: projections to subcortical autonomic, motor, and limbic centers. J Comp Neur 492:145-177. CrossRef Medline

Gee S, Ellwood I, Patel T, Luongo F, Deisseroth K, Sohal VS (2012) Synaptic activity unmasks dopamine D2 receptor modulation of a specific class of layer $\mathrm{V}$ pyramidal neurons in prefrontal cortex. $\mathrm{J}$ Neurosci 32:4959-4971. CrossRef

Groh A, Meyer HS, Schmidt EF, Heintz N, Sakmann B, Krieger P (2010) Cell-type specific properties of pyramidal neurons in neocortex underlying a layout that is modifiable depending on the cortical area. Cereb Cortex 20:826-836. CrossRef Medline

Hattox AM, Nelson SB (2007) Layer V neurons in mouse cortex projecting to different targets have distinct physiological properties. J Neurophysiol 98:3330-3340. CrossRef

Kehne JH, Baron BM, Carr AA, Chaney SF, Elands J, Feldman DJ, Frank RA, van Giersbergen PL, McCloskey TC, Johnson MP, McCarty DR, Poirot M, Senyah Y, Siegel BW, Widmaier C (1996) Preclinical characterization of the potential of the putative atypical antipsychotic MDL 100,907 as a potent 5-HT2A antagonist with a favorable CNS safety profile. J Pharmacol Exp Ther 277:968-981. Medline

Koester SE, O'Leary DD (1993) Connectional distinction between callosal and subcortically projecting cortical neurons is determined prior to axon extension. Dev Biol 160:1-14. CrossRef

Leone DP, Srinivasan K, Chen B, Alcamo E, McConnell SK (2008) The determination of projection neuron identity in the developing cerebral cortex. Curr Opin Neurobiol 18:28-35. CrossRef Medline

Madison DV, Nicoll RA (1984) Control of the repetitive discharge of rat CA 1 pyramidal neurones in vitro. J Physiol 354:319-331. Medline

Molnar Z, Cheung AF (2006) Towards the classification of subpopulations of layer $\mathrm{V}$ pyramidal projection neurons. Neurosci Res 55:105-115. CrossRef Medline

Molyneaux BJ, Arlotta P, Menezes JR, Macklis JD (2007) Neuronal subtype specification in the cerebral cortex. Nat Rev Neurosci 8:427-437. CrossRef Medline

Saldanha AJ (2004) Java Treeview-extensible visualization of microarray data. Bioinformatics 20:3246-3248. CrossRef Medline

Schwindt PC, Spain WJ, Crill WE (1992) Calcium-dependent potassium currents in neurons from cat sensorimotor cortex. J Neurophysiol 67:216-226. CrossRef Medline

Schwindt PC, Spain WJ, Foehring RC, Chubb MC, Crill WE (1988) Slow conductances in neurons from cat sensorimotor cortex in vitro and their role in slow excitability changes. J Neurophysiol 59:450-467. CrossRef Medline

Sesack SR, Deutch AY, Roth RH, Bunney BS (1989) Topographical organization of the efferent projections of the medial prefrontal cortex in the rat: an anterograde tract-tracing study with Phaseolus vulgaris leucoagglutinin. J Comp Neur 290:213-242. CrossRef Medline

Shepherd GM (2013) Corticostriatal connectivity and its role in disease. Nat Rev Neurosci 14:278-291. CrossRef Medline

Spain WJ (1994) Serotonin has different effects on two classes of Betz cells from the cat. J Neurophysiol 72:1925-1937. CrossRef Medline

Stephens EK, Avesar D, Gulledge AT (2014) Activity-dependent serotonergic excitation of callosal projection neurons in the mouse prefrontal cortex. Front Neural Circuits 8:97. CrossRef Medline

Stocker M, Krause M, Pedarzani P (1999) An apamin-sensitive $\mathrm{Ca} 2+$-activated $\mathrm{K}+$ current in hippocampal pyramidal neurons. Proc Natl Acad Sci Usa 96:4662-4667. Medline

Tasic B, et al. (2016) Adult mouse cortical cell taxonomy revealed by single cell transcriptomics. Nat Neurosci 19:335-346. CrossRef

van Aerde KI, Feldmeyer D (2015) Morphological and physiological characterization of pyramidal neuron subtypes in rat medial prefrontal cortex. Cereb Cortex 25:788-805. CrossRef Medline 
van Aerde KI, Qi G, Feldmeyer D (2015) Cell type-specific effects of adenosine on cortical neurons. Cereb Cortex 25:772-787. CrossRef Medline

Van Bockstaele EJ, Biswas A, Pickel VM (1993) Topography of serotonin neurons in the dorsal raphe nucleus that send axon collaterals to the rat prefrontal cortex and nucleus accumbens. Brain Res 624:188-198. Medline

Vertes RP (1991) A PHA-L analysis of ascending projections of the dorsal raphe nucleus in the rat. J Comp Neur 313:643-668. CrossRef Medline

Villalobos C, Andrade R (2010) Visinin-like neuronal calcium sensor proteins regulate the slow calcium-activated afterhyperpolarizing current in the rat cerebral cortex. J Neurosci 30:14361-14365. CrossRef
Villalobos C, Beique JC, Gingrich JA, Andrade R (2005) Serotonergic regulation of calcium-activated potassium currents in rodent prefrontal cortex. Eur J Neurosci 22:1120-1126. CrossRef Medline

Villalobos C, Foehring RC, Lee JC, Andrade R (2011) Essential role for phosphatidylinositol 4,5-bisphosphate in the expression, regulation, and gating of the slow afterhyperpolarization current in the cerebral cortex. J Neurosci 31:18303-18312. CrossRef Medline

Villalobos C, Shakkottai VG, Chandy KG, Michelhaugh SK, Andrade $R$ (2004) SKCa channels mediate the medium but not the slow calcium-activated afterhyperpolarization in cortical neurons. J Neurosci 24:3537-3542. CrossRef Medline

Zhang ZW (2003) Serotonin induces tonic firing in layer V pyramidal neurons of rat prefrontal cortex during postnatal development. $J$ Neurosci 23:3373-3384. 